RETIREMENT BEHAVIOUR AND RETIREMENT INCENTIVES IN SPAIN

Raquet Vegas, tsabel Argimon. Mnarta Botella and clara 1 Gonzalez

Documentos de Trabajo. N. 0913

Bancone ESPANA

\author{
Eurosistema
}


RETIREMENT BEHAVIOUR AND RETIREMENT INCENTIVES IN SPAIN 


\section{RETIREMENT BEHAVIOUR AND RETIREMENT INCENTIVES IN}

\section{SPAIN}

Raquel Vegas

FEDEA

Isabel Argimón and Marta Botella

BANCO DE ESPAÑA

Clara I. González

FEDEA

(*) The authors would like to thank Pablo Hernández de Cos, an anonymous referee and participants at the Workshop on "Economic well-being and social protection in Southern Europe: changing policies and trends", organised by the Instituto de Estudios Fiscales (November 2007), and at the VIII Jornadas de Política Económica, Valencia (October 2007). The opinions and analyses are the responsibility of the authors and, therefore, do not necessarily reflect those of the Banco de España. 
The Working Paper Series seeks to disseminate original research in economics and finance. All papers have been anonymously refereed. By publishing these papers, the Banco de España aims to contribute to economic analysis and, in particular, to knowledge of the Spanish economy and its international environment.

The opinions and analyses in the Working Paper Series are the responsibility of the authors and, therefore, do not necessarily coincide with those of the Banco de España or the Eurosystem.

The Banco de España disseminates its main reports and most of its publications via the INTERNET at the following website: http://www.bde.es.

Reproduction for educational and non-commercial purposes is permitted provided that the source is acknowledged.

\section{(c) BANCO DE ESPAÑA, Madrid, 2009}

ISSN: 0213-2710 (print)

ISSN: 1579-8666 (on line)

Depósito legal: M. 36642-2009

Unidad de Publicaciones, Banco de España 


\section{Abstract}

In this paper we analyse the role that Social Security wealth and incentives play in the transition to retirement in Spain. We use the labour records and other relevant information contained in a newly released database [Muestra Continua de Vidas Laborales (2006)] to construct incentive measures stemming from the Social Security provisions in relation to retiring at old age and investigate the role played by such incentives and by other socio-economic variables on the retirement hazard. We compute the effects of the reform that took place in 2002, which made the requirements to access a pension stricter in general. We carry out a dynamic reduced-form analysis of the retirement decision using a duration model.

Our results show that both the pension wealth and substitution effects have a significant role on retirement decisions, but that the latter has less relevance since the reform introduced in 2002.

Keywords: older workers employment, retirement, public pensions.

JEL Classification: J14, J26. 
The rise of pension expenditure is a matter of concern in ageing economies, such as Spain, as social security systems were designed at a time when demographic structures were characterised by a much lower life expectancy and a much higher fecundity'. Therefore, both, the number of retired people and the retirement period were much lower when the system was launched than nowadays².

On top of such demographic developments, we observed, up to the early nineties, a decline in the labour force participation of older workers, which has recovered since, attaining the levels reached in the late eighties. The combination of both factors has lead to the prediction that the ratio between people in working age and people of 70 or more years of age, which is nowadays around 5.5 in Spain, will be only 2.25 in 2055. So, a smaller proportion of people will be providing the revenue that will be transferred to older people in the form of pensions. In this sense, the behaviour of older workers is contributing to the increase in pension expenditures.

The role of pension benefit rules in relation to labour market participation of the elderly is regarded as central in many countries, as they may create incentives to retire early from work. In this sense, three issues are relevant here: the amount of the pension that the system provides, the pattern of benefits associated with each age of retirement and the entitlement rights that define the conditions to be met to be able to claim a pension at each age. Parametric changes for the Social Security system have been and are being discussed in Spain under the so-called Toledo Agreement while some countries have already implemented large reforms. Many changes have been directed to reducing incentives to early retirement embedded in the pension system and to increase incentives to leave the labour market at a later age. Governments have also promoted active labour force measures that should stimulate the demand for elderly workers, thus contributing to raising or maintaining labour market participation of the elderly.

The goal of this paper is to study and quantify the role that Social Security provisions for old-age pensions are playing on the retirement decision of the elderly in Spain. We propose estimating a reduced form model for retirement to capture the effects of pension incentives on pension claiming, controlling for some socio-demographic characteristics. In particular, we analyse the probability of retiring at a given age, given that the person has not retired yet, as a function of individual variables.

Boldrin et al. (1999 and 2004) have carried out an analysis of similar characteristics, estimating the probability of retiring at a given date. The objective of the work that we are presenting here is to widen such study in three main directions. On the first place, we propose estimating a duration model and not a point in time estimation, so as to allow a consideration of the determinants of the retirement decision at different ages, and, particularly

1. It is the decline in fecundity, more than the longevity increase, what explains the forecast that more than $30 \%$ of total Spanish population will be older than 65 years of age in the middle of this century.

2. In fact, the average number of years that a man aged 65 was expected to live from that age was around 12 in the middle of the 20th century, it has grown up to 15 now, and is forecasted to increase to 20 years in the middle of this century, according to the Spanish National Statistics Institute (Instituto Nacional de Estadística, INE). 
to assess the role of the SS incentives for early retirement and for retirement at each age ${ }^{3}$. Moreover, we use a new database, the Muestra Continua de Vidas Laborales (MCVL), which has recently been released to explore this issue further. The advantage of the MCVL for the analysis in relation to previous samples obtained from the same source, and used in empirical work $^{4}$, is that the sample design is known and, therefore, it allows for a better and broader understanding of the results obtained. A duration approach seems to maximize the informative content of this database, as it allows following the workers' decisions across time. Finally, we address the quantification of the impact of the change in pension rules whose full implementation took place in 2002.

The paper is structured as follows. In the next section, we briefly summarise the empirical results obtained so far on the determinants of retirement for old people in Spain. Section 3 contains a description of the dataset that we use in the analysis. In section 4 we discuss the empirical model that we estimate and whose results are summarised in section 5 . Section 6 contains the conclusions. A data appendix is included, as well as an appendix containing the main features of the Spanish Social Security pension system.

3. Villagarcía (1995) and Muñoz (1995) apply the duration model approach to analyse the age of retirement, using the EPA database, which is cross sectional by construction. Because of the data source they cannot address the role played by SS incentives.

4. A previous version of a similar database with information up to 1995 and whose description can be found in Martínez (1999), has been used in Boldrin et al. (1999 and 2004), Boldrin and Jiménez-Martín (2002), and Jimenez-Martín et al. (2000 and 2006). The main drawbacks of such database are that the detailed sample design has not been disclosed and that it is not publicly available. 


\section{The empirical analysis of the role of Social Security on retirement decisions}

The vast majority of empirical analysis carried out to measure the role of Social Security on retirement decisions has been done for the USA, while evidence for other countries, and specially Spain, is more limited 5 .

One of the most revealing evidence of the dependency between withdrawal from labour force and pension regulations in Spain is the presence of spikes in the benefit claiming moment around the ages of 60 , the earliest age a pension can be, in general, claimed, and 65, the ordinary retirement age. Such pattern is also observed in other western countries [Gruber and Wise (1999 and 2004)], where eligibility ages prescribed in country-specific provisions also play a major role in defining the observed pattern of retirement by age.

The microeconomic evidence that has been gathered so far shows that the Spanish early retirement provisions play an important role in the modal age of retirement and its pattern in different ages [Boldrin et al. (1999 and 2004)] and that, in general, labour force transitions of elderly men depend on Social Security regulations [Alba (1997), García-Pérez and Sánchez-Martín (2008a and 2008b)] $]^{6}$, and their interdependence with health considerations Blanco (2000) and Prieto et al. (2002).

There are few papers that attempt at quantifying the impact of pension Social security incentives on labour force participation. In particular, Boldrin et al. (1999 and 2004) and Jiménez (2006) do so through changes in the social security framework. These works follow a regression-based approach, being based on reduced-form behavioural equations, to model the effect on the decision to retire of pension wealth, the incentives embedded in the pension system and individual demographic characteristics. Estimating retirement hazard rates, using a probit model on a sample of individual work histories randomly drawn from the historical files of Social Security affiliates, they conclude that a substantial portion of the retirement behaviour cannot be explained by Social Security factors. On the other hand, García-Pérez and Sánchez-Martín (2008b) find evidence of the relevance of the social security incentives on the transitions from unemployment for older workers. Using a sample of individuals aged between 56 and 70 from the European Union Household Panel (PHOGUE), wave 7 (2000), Utrilla de la Hoz and Ubago (2005) find that a replacement rate (pension over total income) below $80 \%$ reduces the probability of retiring.

The effect of the successive pension reforms has been empirically addressed and point out, in general, to its effectiveness in lowering retirement. Jiménez (2006) carries out a simulation exercise that computes the effect of the Spanish old age pension reforms that took place in 1997 and 2002 and concludes that they reduce the hazard rates. A similar qualitative result is found in Gutiérrez-Domenech (2006), where, using a longitudinal survey of Catalan population, it is shown that the 2002 reform contributed to the increase in the staying-on employed probabilities of the individuals older than 60. On the other hand, Sánchez-Martin (2005), using a calibrated overlapping-generations model finds that the

5. This literature has been reviewed in detail in Diamond and Gruber (1999) and Coile and Gruber (2000). Evidence for other countries can be found in Gruber and Wise (1999 and 2004), where also the case of Spain is addressed [Boldrin et al. (1999 and 2004)].

6. See García Pérez and Sánchez Martín (2008a and 2008b) for some results on the links between unemployment, retirement and their associated public insurance programmes calibrated with data from the MCVL. 
overall effect of the 2002 reform is a clear drop in the average retirement age, as younger cohorts of low income workers benefit from the opportunity of leaving the labour force early.

As for the impact of truncations in the system, Jiménez-Martín and Sánchez (2000 and 2006) show, through the estimation of the behavioural parameters of a structural model, that the existence of minimum pension's regulations has an impact on early retirement decisions. They find that the combination of age penalties and minimum pensions generate large incentives to early retirement for those workers with low wages and short labour histories. Jiménez-Martín and Sánchez (2006) conclude that there is a threefold increase in retirement at 60 with respect to the economy without minimum pensions and that total early retirement (before or at 60 ) is almost $50 \%$ larger.

Finally, there is the line of research devoted to analysing the sustainability of the pension system which is usually formulated within the framework of an overlapping generations model. The evidence gathered on the effects of delaying the normal retirement age a number of given years [Sánchez-Martín (2003); Boldrin and Jiménez-Martín (2003); Díaz-Giménez and Díaz-Saavedra (2008)] shows that this strategy has an important impact on the system deficit. 


\subsection{The MCVL}

The database Muestra Continua de Vidas Laborales (MCVL 2006) includes all the electronically recorded information that the Social Security administration keeps in relation to labour and contributory pension history for more than one million of individuals, whose anonymity is preserved. It is a $4 \%$ random draw from a reference population, which is composed of all the people who at any time during 2006 had a registered record with the Social Security system, either because they were contributing or because they were receiving a pension. Therefore, it does include those that were unemployed for the whole 2006, either if they received a contributory pension or if they received unemployment benefits, as in the latter case, the National Employment Service pays their social contributions to the Social Security Funds. The sample does not contain any information relating to the scheme called the Regimen de Clases Pasivas that covers public sector employment, so that most civil servants cannot be included in the analysis. It must be pointed out that as a consequence of the definition of the reference population a large proportion of non-working females is also included, mostly as preceptors of a widowhood pension?

Most of the labour, contributory and pension history of the over one million individuals has been recovered, so that their employment history can be reconstructed. The data contain, for each employment spell, information on covered earnings, which are the amount of the earnings that the Social Security regulations takes into account for the computation of pension rights. Covered earnings can be regarded as a good proxy for actual earnings, although they have both a ceiling and a floor: on the one hand, a minimum contribution must be paid over earnings, independently of the actual amount perceived, so that there is a minimum covered earning associated to it; on the other hand, earnings above a given ceiling do not pay contributions and therefore do not generate further rights. Covered earnings are used in the empirical analysis to proxy the wage variable.

Moreover, for each employment spell we have also information on length and type of contract, the Social Security regime and contributive group that are associated with the job and that define the amount of the contributions and the conditions to access the pensions, as well as information about the firm, such as its activity sector and location (province) ${ }^{8}$. Available data also include some personal characteristics such as sex, age, place and year of birth. We can also know the place where the worker first affiliated, which could be regarded as the place where the first job was taken. Data on people's socio characteristics, such as marital status are poorly recorded in the sense that the available information corresponds to the situation when the affiliation took place, and in no case there is any reference to the spouse's working status, so that it is not possible to take into account the joint decision to retire ${ }^{9}$. As far as social transfers are concerned, the database contains information on periods and amounts enjoyed for old-age and disability pensions or survivors' pensions

7. A detailed description of the sample can be found at Seguridad Social (2006), and an overview in Argimón and González (2006).

8. Active policy measures to promote retaining or offering a job to old people cannot be taken into account as the dataset does not include enough information to do so.

9. The MCVL has been matched with information coming from the Census. In the Census' module "Co-inhabitants" there is information about the number of people living with the person in the MCVL dataset, their age and sex, but not their working status. 
such as, orphanage, widowhood and family help. There is no data on other sources of individual wealth or other sources of income ${ }^{10}$.

\subsection{The subsample}

Given that we are only interested in retirement decisions taken by the elderly, we restrict our initial sample from the 2006 wave to people that are aged between 60 and 70 in 2006 (i.e. those born between 1936 and 1946) and that have already become entitled to a pension benefit, defined in terms of being able to prove at least 15 contributory years. It means that we exclude those for which the Social Security system does not record any contributory life, those that have retired before their $60^{\text {th }}$ birthday ${ }^{11}$ and those who started receiving an old age pension before 1997, when a large pension reform was introduced ${ }^{12}$. We have also excluded those that receive an old-age pension coming from incapacity, as the determinants to claim such kind of pension are most likely linked to health factors, which are not comparable with the rest of the determinants ${ }^{13}$. We additionally restrict the sample to men as the labour history of women is quite different from the one for males, so that the determinants of their decisions may be rather different. Finally, to ensure homogeneity in pension rules, the sample is limited to those whose longest recorded labour relation has taken place in the General Regime, the Social Security scheme that gathers the largest proportion of workers ${ }^{14}$.

Finally, we also exclude some individuals with incomplete recorded contributory information so that the sub-sample we use for the analysis is composed of 35,853 men, whose distribution by year of birth and retirement age is reflected in Table 1.

Table 1

Distribution by year of birth and retirement age. Sample of men born between 1936 and 1946 having worked in the General Regimen and with a relation with the Social Security in 2006

\begin{tabular}{|c|c|c|c|c|c|c|c|c|}
\hline Born & & & & & & & Not retired & Total \\
\hline & 60 & 61 & 62 & 63 & 64 & 65 & & \\
\hline 1936 & & 205 & 199 & 152 & 295 & 892 & 189 & 1,932 \\
\hline 1937 & 880 & 201 & 162 & 149 & 295 & 866 & 195 & 2,748 \\
\hline 1938 & 817 & 136 & 159 & 153 & 285 & 819 & 170 & 2,539 \\
\hline 1939 & 652 & 103 & 135 & 134 & 243 & 732 & 190 & 2,189 \\
\hline 1940 & 948 & 168 & 225 & 232 & 401 & 1,225 & 314 & 3,513 \\
\hline 1941 & 704 & 140 & 187 & 192 & 332 & 981 & 893 & 3,429 \\
\hline 1942 & 607 & 186 & 170 & 188 & 350 & & 1,956 & 3,457 \\
\hline 1943 & 600 & 213 & 231 & 205 & & & 2,671 & 3,920 \\
\hline 1944 & 554 & 200 & 220 & & & & 2,963 & 3,937 \\
\hline 1945 & 546 & 209 & & & & & 3,449 & 4,204 \\
\hline 1946 & 388 & & & & & & 3,597 & 3,985 \\
\hline Total & 6,696 & 1,761 & 1,688 & 1,405 & 2,201 & 5,515 & 16,587 & 35,853 \\
\hline
\end{tabular}

10. The MCVL has also been matched to Personal Income Tax data corresponding to one fiscal year. In that sense, information on additional sources of income could be obtained, but not in a longitudinal dimension.

11. Early retirement before the age of 60 is only possible for dangerous and unhealthy jobs such as air pilots, some miners, railways workers, bullfighters and artists.

12. Very few records relating to pensions awarded before 1997 are available.

13. Moreover, the transition to the old-age retirement scheme is deterministic, so that disability pensions are converted into retirement pensions once the beneficiaries turn 65 years of age. These pensions receive a very favourable tax treatment.

14. See the Appendix on legislation for a description of the regulatory framework. 


\section{$4 \quad$ Empirical framework}

The earliest empirical work in this area considered reduced-form models of the retirement decision as a function of Social Security wealth and pension level. While the estimation strategies employed differed, depending mainly on the nature of available data, the results consistently suggested a role for Social Security. The main limitation of this type of studies is that they consider Social Security effects at a point in time, but cannot account for the impact on retirement decisions arising from the time pattern of social security wealth accruals. In order to address this shortcoming, different approaches were followed in subsequent analysis. The accrual of Social Security or other more forward-looking incentive measures were developed and their effect was analysed with the estimation of reduced-form models ${ }^{15}$. Alternatively, a different approach was to consider structural models where workers were facing a budget constraint which was discontinuous or kinked ${ }^{16}$. Another line of research is the "option value" model of retirement where it is postulated that not only the level of pension wealth or its increment with one additional year of work is a determinant of the retirement decision, but that what is relevant is the evolution of future wealth and work. So retirement decisions are modelled as a function of the difference between the utility of retirement at the current date and at the date that maximizes one's utility [Stock and Wise (1990)]. In its structural form this model is difficult to implement, so numerous authors [Samwick (1998); Gruber and Wise (1999); Hakola (2002); Blundell et al. (2002)] have used the option value in reduced form models. More recently, applied general equilibrium models are also being used to explore the pensions issue [for instance, Imrohoroglu et al. 1999)] so that they need to be calibrated to be able to produce numerical results ${ }^{17}$.

The paper follows the hazard model approach followed in Grubber and Wise (2004), and Blundell et al. (2002), among others, to capture the effects of changes in social security wealth and other variables on retirement. Although the option value model is the theoretically most intuitive model and the structural model should provide more insight into the issue, we choose the simplicity of this reduced form technique because of the computational complexity of the alternative approaches ${ }^{18}$. Moreover, it is partially forward looking, as it allows for continuous updating of information as individuals grow older. That is, for an individual who complies with the requirements to retire at age t, the probability of retiring at age $t+1$ is modelled in terms of the ratio of annual wage earnings over pension benefits, public pension accruals and labour situation at time t. The retirement decision is analysed in this paper following a duration model approach that treats it as a dynamic discrete choice ${ }^{19}$.

We define $\mathrm{T}$ (our duration variable) as the period between the age the person becomes entitled to receive a retirement pension until the age that person claims the benefit.

15. Spataro (2005) proposes a set of alternative measures that feature the forward-looking aspect and applies them to Italian data.

16. The lifetime budget constraint is analogous to the standard labor-leisure budget constraint, with annual hours replaced by years of labour force participation, and annual earnings replaced by cumulative lifetime compensation. The kinks are produced by changes in the accrual rates (the rise in retirement income entitlement caused by continuing to work for one more year). See, for instance, Burtless (1986).

17. See Jimeno et al. (2006) for a survey of the features of different approaches used in the literature to study the effects of population aging on Social Security expenditures.

18. Moreover Spataro (2002) finds that a reduced-form model is preferable to the structural option value model.

19. We assume that individuals will choose to remain with the current situation if the utility of remaining exceeds the utility of retiring 
We treat it as a discrete variable, defined in years, that changes as time goes by ${ }^{20}$. We let $C_{i}$ be the maximum number of years that we could observe the individual in the sample, which only depends on his year of birth and the moment he became eligible, so that it is constant. So, that, for example, if a person born in 1941, becomes eligible in 2001 (when he is 60), and only claims a pension benefit in 2003 (when he is 62), will have in 2004, T=3 and $\mathrm{C}=5$. In our estimation we restrict $C_{i}$ to be at least 1 and no greater than 6 as we assume that the decision to retire only takes place between 60 and 66 , as only very few people retire after that age, or do not retire at all. The dataset contains some individuals that either can only be observed before they take the decision of interest (i.e. claim pension benefit) because we only observe the individuals up to the year 2006 or either did not claim a retirement pension before the age of 66. In both cases, data is right censored. For these individuals we can only observe that $\mathrm{T}>\mathrm{C}$, so that they remain in the current situation for a larger number of years than the ones that the sample allows us to observe them. That is, we observe claiming at $T$ only if $\mathrm{T}=<\mathrm{C}$. Otherwise, we observe that $\mathrm{T}>\mathrm{C}$. We assume that $\mathrm{T}$ is independent of $\mathrm{C}^{21}$.

The intensity of transition to claiming or the hazard function (i.e. the probability of an individual retiring precisely at time $t$, given that he has not retired before $t$ ), is defined as:

$\phi\left(t_{i} \mid X_{i}\right)=\operatorname{prob}(T=t \mid T>=t)=\operatorname{prob}(T=t) / \operatorname{prob}(T>=t)=F\left[\theta_{0}(t)+\theta_{1}(t) x(t)\right]$

where $X_{i}$ is a vector of explanatory variables, some of which are age dependent and others are constant and independent of the age. It provides the probability of not claiming benefits for exactly $t$ years relative to the group of individuals who have been not claiming for at least $t$ years. In other words, it gives the probability of retiring $T$ years after having become entitled to a pension, given that the person has not retired before.

A discrete duration model can be regarded as a sequence of binary choice equations (with cross equation restrictions) defined on the survival population at each duration. $\mathrm{x}: F\left(t_{i} \mid x_{i}\right)$

We are, therefore, interested in the conditional distribution of $\mathrm{T}$ in relation to variables

So the likelihood function could be expressed as:

$$
\begin{aligned}
& L=\sum_{i=1}^{N-C} \ln f\left(t_{i} \mid x_{i}\right)+\sum_{i=N-C+1}^{N} \ln \left(1-F\left(t_{i} \mid x_{i}\right)\right) \\
& L=\sum_{i=1}^{N-C} \ln \left[\phi\left(t_{i}, x_{i}\right) \exp \left(-\int_{b}^{i} \phi\left(u, x_{i}\right) d u\right)\right]+\sum_{i=N-C+1}^{N} \ln \exp \left(-\int_{b}^{i} \phi\left(u, x_{i}\right) d u\right)
\end{aligned}
$$

where $\phi$ is the vector of parameters to be estimated.

20. We must remind that not all individuals in the sample are either working or have claimed an old-pension. Some of them are unemployed and receive benefits, some do not receive benefits, but are also contributing and some do not contribute. Moreover, some go through different labour situations before claiming the pension. [See Argimón, González and Vegas (2007)]. The situation immediately preceding retirement is conditioned upon, but duration is defined independently of the situation.

21. It must be reminded that for some cohorts we can only have observations of people retiring after a given age (60 for those born in 1936) or before a given age (for instance, at most at 60 for those born in 1946), in the latter case, given that this is the age when the sample was extracted, as shown in Table 1. 
The dependent variable in the model is the probability of retiring (claiming a retirement pension) at a specific age, given that the person has become eligible to do $\mathrm{so}^{22}$ and has not retired the preceding years ${ }^{23}$. The explanatory variables that have been included in the specification $\left(X_{i}\right)$ can be grouped in three main categories: social security framework, personal characteristics, and labour characteristics. A detailed description of the variables that have been used can be found in Appendix 1.

We build up the traditional measures of the incentive mechanisms that are standard in this literature. In particular, we use the Replacement Rate (RRt), which is the ratio of the expected pension benefits over wages, the Social Security Wealth $\left(\mathrm{SSW}_{\mathrm{t}}\right)$, that is, the present discounted value of the future stream of pension benefits, the Accrual Rate (SSA ) which measures the discounted increase in SSW from postponing retirement one year and the Peak Value $\left(P V_{t}\right)$, that compares this year's social security wealth to the maximum social security wealth that could be attained in the future. They are constructed under the assumptions that the age of death is certain, no changes in social security regulation are expected by individuals and it excludes any tax considerations.

Table 2 provides information about the descriptive values of the incentive Social Security variables showing that, while the average stock of wealth was higher after the 2002 reform than before, the incentives linked to it were lower. On the other hand, the RR increased after the reform. It also contains information related to working status, distinguishing between those observations corresponding to a working situation (I) previous to the decision moment and those corresponding to an unemployment situation (u). The rest of the observations correspond to either an already retired situation or another situation where there is no work involved. Information concerning the rest of the variables can be found in Table A1 of the appendix.

22. It could be the case that they withdrew the labour market much in advance and remained unemployed or were inactive for some time. In fact, in the case of Spain, early retirement regulation stipulates that in some cases, workers need to be unemployed to be able to claim retirement pensions before the age of 65 , the ordinary retirement age. Moreover, up to 2002, pension regulations required total or substantial withdrawal from any form of employment requiring affiliation to the Social Security System to be able to perceive an old-age pension. In 2002, partial retirement was regulated, so that employment and old-age pensions could be simultaneously enjoyed, while the mandatory retirement age at 65 was effectively abolished (see Cairó (2007)). An alternative would be to study the transitions from employment to a non-employment status, as in Gutiérrez-Domènech (2006).

23. So, for each person, the decision moment is different and is defined in relation to his day of birth, assuming that they are yearly decisions. 
Table 2

Descriptive values of Social Security incentives and working status. Sample of men born between 1936 and 1946, having worked in the General Regimen and with a relation with the Social Security in 2006

\begin{tabular}{|c|c|c|c|c|c|c|c|c|c|}
\hline & \multirow{2}{*}{\multicolumn{3}{|c|}{ All period considered 1996-2006 }} & \multirow{2}{*}{\multicolumn{3}{|c|}{ Before 2002}} & \multirow{2}{*}{\multicolumn{3}{|c|}{ After 2002}} \\
\hline & & & & & & & & & \\
\hline & median & mean & s.d. & median & mean & s.d. & median & mean & s.d. \\
\hline $\operatorname{ssw}_{t}^{(1)}$ & 199.30 & 222.50 & 96.83 & 195.83 & 211.84 & 87.02 & 201.35 & 228.17 & 101.21 \\
\hline $\operatorname{SSA}_{t}^{(1)}$ & 6.89 & 6.73 & 12.95 & 10.12 & 9.79 & 12.20 & 4.97 & 5.09 & 13.04 \\
\hline $\mathrm{PV}_{\mathrm{t}}^{(1)}$ & 12.65 & 18.84 & 26.73 & 21.68 & 26.77 & 28.03 & 8.32 & 14.63 & 25.01 \\
\hline $\mathbf{R R}_{\mathrm{t}}^{(2)}$ & 57.61 & 67.36 & 35.50 & 50.77 & 57.61 & 26.56 & 61.93 & 72.55 & 38.45 \\
\hline$I_{t-1}^{(2)}$ & \multicolumn{3}{|c|}{57.49} & \multicolumn{3}{|c|}{62.67} & \multicolumn{3}{|c|}{54.74} \\
\hline$u_{t-1}^{(2)}$ & \multicolumn{3}{|c|}{24.28} & \multicolumn{3}{|c|}{27.54} & \multicolumn{3}{|c|}{22.55} \\
\hline $\mathbf{N}$ & \multicolumn{3}{|c|}{115,532} & \multicolumn{3}{|c|}{40,123} & \multicolumn{3}{|c|}{75,409} \\
\hline $\mathrm{n}$ & \multicolumn{3}{|c|}{35,853} & \multicolumn{3}{|c|}{16,212} & \multicolumn{3}{|c|}{28,259} \\
\hline
\end{tabular}

We make that both the level of social security wealth and the different incentive variables enter the equation. The level captures wealth effects: the larger the value of wealth, the larger the demand of all goods, including leisure, if leisure is a normal good. The incentive variables capture a substitution effect: the higher the price for leisure, the lower its demand, so that if there is a larger financial incentive to additional years of work, then individuals will retire later. The specification chosen also allows us to test whether the sole act of being entitled is a determinant for retirement, in the sense that the individual leaves his current situation as soon as he is entitled to collect a pension benefit. Finally, the impact of the regulatory change introduced from 2002 is also analysed, both as it could have affected the average probability of retiring and through its effects on the incentive mechanisms.

As for the labour characteristics, the control variables include the individual's labour situation the year preceding the decision date, distinguishing between working and unemployed, the activity sector and some measures of labour mobility or precariousness.

Finally, we also include some standard demographic controls such as age, education and health status. We also control for the collection of other benefits as they may interact with the old age pension. Finally, regional dummy variables and GDP growth are also included to control for the macro environment.

The duration dependence of the hazard rate is captured in two ways. On the one hand, following Bover et al. (2002) we do not impose a specific functional form for duration, so that we introduce additive dummy variables for each of the possible discrete values of the duration variable. Durations of more than 6 years (which would necessarily imply that the person is at least 66) are treated as censored at 6 years, due to the relatively small number of observations under such circumstance. On the other hand, interaction of certain independent variables with the duration are included to see if the variable effects change with the number of years that a person takes to retire. Table A1 in Appendix 1 contains the summary of the variables used. 


\section{$5 \quad$ Results}

The qualitative impacts of the variables on the hazards are discussed in terms of the sign and statistical significance of the estimated coefficients, which are reported in detail in Table A2 in Appendix 1. We present in that Table three different specifications with two different sets of Social Security incentive variables. So, under model A we present the estimated coefficients obtained for the basic specification, distinguishing between the Accrual Rate (SSA) as incentive variable, and the Peak Value (PV). Model B tries to capture the impact of the 2002 reform through the inclusion of dummy variables that test for its relevance and effect on the response to the social security variables, while model $\mathrm{C}$, also include dummy variables that capture the effect on the retirement hazard rate of being entitled to perceive the minimum or the maximum pension benefit at each age.

The size of the impacts of the Social Security measures on the probability of retiring is reported in Table 3. In particular, they are measured as the predicted effect of a change in the Social Security variable on the hazard, computing it as an elasticity, for the variables that are continuous. For the qualitative ones, its impact is computed from the change from 0 to 1 in the variable, so that they can be interpreted as the direct effect of having such characteristics on the probability of retiring. The more detailed quantitative impact of a change in all the variables included in the specification distinguishing by age is reported in Table A3 of Appendix 1.

Table 3

Quantitative effects of Social Security measures on the retirement probability ${ }^{(*)}$

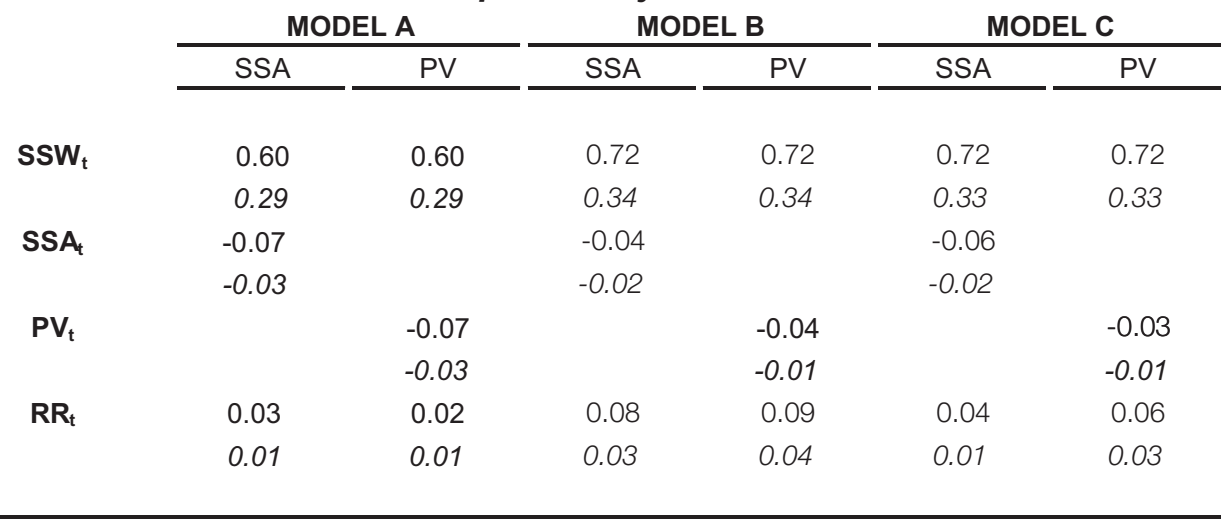

${ }^{(*)}$ Quantitative effects are computed as the discrete differences of the logistic function evaluated at a $10 \%$ increase in the variables' values with respect to the logistic function evaluated at the observed variables' values.

Results are obtained from the regressions presented in Table A2 where:

Model A represents the basic model.

Model B represents Model A including changes in 2002 regulation as control variables.

Model $\mathrm{C}$ includes Model $\mathrm{B}$ and income level as control variables.

Median values are in italics 


\subsection{Economic incentives and regulation}

As the results in Table A2 show, all the social security variables coefficients -for SSW, SSA and PV- are statistically significant with the expected sign. Increases in the total present value of the flow of pensions that a person will receive from the year she retires to the year she dies, i.e. an increase in SSW, increases the hazard. Increases in the difference of this amount derived from postponing the retirement (either one or more years) reduce the hazard, whether SSA or PV are used to capture the substitution effect.

In order to provide an assessment of the explanatory power of the different variables, whose statistical significance has been tested, for the hazard rate, we propose using the Akaike (AIC) and the Bayesian Information criteria (BIC), as recorded in Table 4. By providing a criterion to choose among nested models, we can compare the relative explanatory power of the different variables to affect the probability of retiring. As shown, the pension wealth and the incentive measures are jointly significant (Table 4) for all specifications. On pure likelihood grounds, the specification that does include the peak value dominates the one with the more myopic incentive measure.

Table 4

Relative incidence of Social Security measures on retirement decisions for all the period considered $^{(*)}$

\begin{tabular}{|c|c|c|c|c|c|c|}
\hline & \multicolumn{3}{|c|}{ SSA } & \multicolumn{3}{|c|}{ PV } \\
\hline Contribution of & AIC & $\mathrm{BIC}$ & In Likelihood & AIC & $\mathrm{BIC}$ & In Likelihood \\
\hline Overall Model C & 65659.72 & 66210.18 & $-32772.86(57)$ & 65648.87 & 66199.34 & $-32767.44(57)$ \\
\hline $\mathrm{SSW}_{\mathrm{t}}$ & 66186.56 & 66717.71 & $-33038.28(55)$ & 66164.28 & 66695.43 & $-33027.14(55)$ \\
\hline $\mathrm{SSA}_{\mathrm{t}}$ & 65694.62 & 66225.77 & $-32792.31(55)$ & 65694.62 & 66225.77 & $-32792.31(55)$ \\
\hline $\mathrm{RR}_{\mathrm{t}}$ & 65659.82 & 66190.97 & $-32774.91(55)$ & 65656.79 & 66187.94 & $-32773.39(55)$ \\
\hline $\mathrm{SSW}_{\mathrm{t}}$ and $\mathrm{SSA}_{\mathrm{t}}$ & 66212.33 & 66724.17 & $-33053.17(53)$ & 66212.33 & 66724.17 & -33053.17 (53) \\
\hline $\mathrm{SSW}_{\mathrm{t}}$ and $\mathrm{RR}_{\mathrm{t}}$ & 66201.02 & 66712.86 & $-33047.51(53)$ & 66188.33 & 66700.17 & -33041.17 (53) \\
\hline $\mathrm{SSA}_{\mathrm{t}}$ and $\mathrm{RR}_{\mathrm{t}}$ & 65703.37 & 66215.21 & $-32798.69(53)$ & 65703.37 & 66215.21 & -32798.69 (53) \\
\hline $\mathrm{SSW}_{\mathrm{t}}, \mathrm{SSA}_{\mathrm{t}}$ and $\mathrm{RR}_{\mathrm{t}}$ & 66226.46 & 66718.98 & $-33062.23(51)$ & 66226.46 & 66718.98 & $-33062.23(51)$ \\
\hline r2002 & 65787.63 & 66299.47 & $-32840.81(53)$ & 65792.13 & 66303.96 & $-32843.06(53)$ \\
\hline
\end{tabular}

${ }^{(*)}$ Results are obtained from regressions under Model C of Table A 2. Degress of freedom in parenthesis.

Number of observations: 115,532 .

In spite of these effects being statistically significant, their size is not very large. As the figures in Table 3 show, a 10\% rise in SSW, increases on average around 7 percentage points the probability of retiring between 60 and 65 years of age. Moreover, these probabilities show a U-shaped form with age (Table A3), reaching the highest impact at 65 , so that the closer the person is to that age, the more responsive to changes in SSW she becomes.

As for the incentive variables, we find that increasing by $10 \%$ the difference between what a worker would receive if she retired now and what she would receive if she retired one year later (increasing SSA) decreases the average probability of retiring between 60 and 65 by between 0.3 and $0.7 \mathrm{pp}$ and by a similar amount if the $10 \%$ increase would be in PV. The effects on the retirement probability of the SSA and PV incentives are also U-shaped in 
relation to age (Table A3), so that they are large at 60, decline then and later start increasing again.

On the other hand, the replacement rate, does show the positive expected sign for the whole sample, but it is not statistically significant, a finding which is confirmed by the results on the AIC and the BIC criteria shown in Table 4.

From the calculations presented in Table 4 we could conclude that the wealth variable plays a larger role on the determination of the hazard rate than any of the incentive variables. That could imply that changing the quantity that is transferred through pensions is more relevant to retirement decisions than changing the built-in incentives in the regulation.

The observed probability of retiring between 60 and 65 before 2002 is higher than after 2002 and this relationship happens at every of the ages between 60 and 65 (Figure 1). The role of the 2002 reform on this change is tested with both the introduction of a dummy variable that takes value 1 from 2002 onwards and which may capture changes in tastes or other factors that are not channelled through the Social Security variables, and with the inclusion of this dummy variable interacted with the Social Security incentive and pension wealth.

Figure 1 Predicted hazard rates before and after 2002 by age

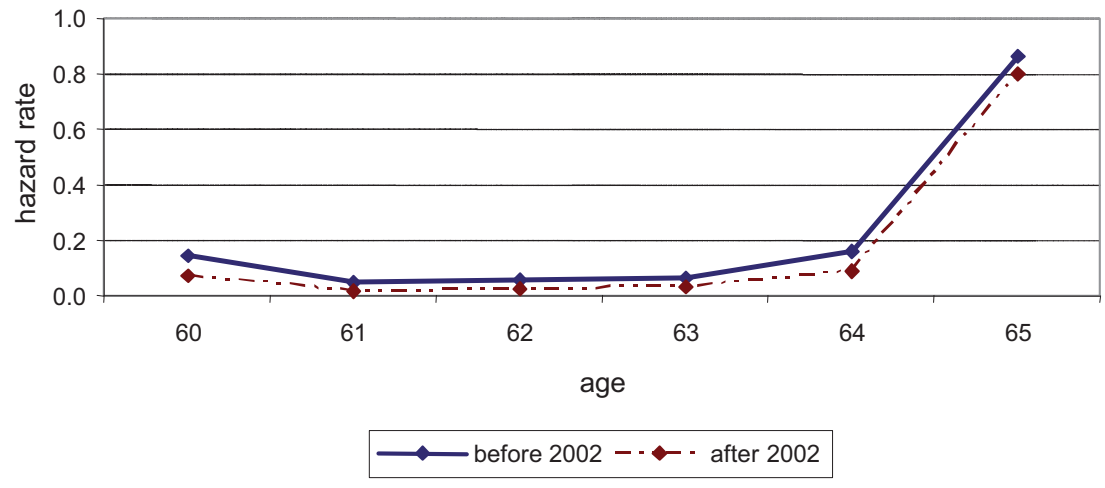

If we use the sign and the t-ratios of both the dummy and the interacted variables to test for significance of the changes that were introduced in $2002^{24}$, we can conclude that the reform did not change the pattern of response to the wealth variable, but the response to the incentive variables, in general, reducing its impact on the timing of retirement (Table A 2). That is: we need a larger value of SSA (or PV) from 2002 to reach the same impact on the hazard, as shown in Table A 4, where a decomposition of the effects of the reform on the incidence of the different incentive variables is shown. This result could be explained as a consequence of the fact that one of the changes carried out under the reform improved the treatment for those that had more than 30 years of contribution, increasing for them the amount of the pension to be perceived at each age. The fact that most workers (64\%) already had at least 30 contributory years (in particular, nearly a third had more than 34 years of contributions), may explain the finding that the reform reduced the incidence of the incentive structure. Additionally, the replacement rate becomes statistically significant for this period, so that a more myopic approach seems to result. Therefore, the observed reduction in the hazard rate does not seem to stem from the new

24. See Norton et al. (2004) for a discussion of such test. 
regulation, which has reduced its incidence, but from a collection of other factors that are captured by the dummy.

The evidence gathered shows that those individuals that are being low topped in terms of the amount of their Social Security wealth have a higher retirement probability at 60 than those that are not (Table A 4). It could be argued that the minimum pension mechanism blocks the effect of early retirement penalties so that it creates a strong incentive for low income earners to retire, that is specially strong at 60 . From 61 onwards being low topped in wealth reduces the probability of retiring. In fact, the older the person, the higher is the reduction in the probability to retire. This result could be consistent with the idea that people might choose to carry on working in order to build up more pension rights, given the built-in incentives, arising from the higher dependency between the amount of the pension to be perceived and the latest wages that he receives compared to previous wages, wich, under the expectation that they increase with age, could lead to a larger pension in the future.

The results also show that high earners (those that have their pensions capped) have a lower probability of retiring both at 64 and $65^{25}$ (Table A 4), in line with the findings in Villagarcía (1995), Jiménez-Martín and Sánchez (1999), Blanco (2000) and Labeaga (2008) that show that income plays a positive role on continuing in employment. This finding could result from the fact that, for those workers, financial incentives are not a good proxy for the marginal utility from working, A lower potential wage rate for a mature age worker is likely to be associated with a lower probability of labour force participation, as other things equal, a lower wage rate represents a lower opportunity cost of leisure and a higher replacement rate for government pensions.

\subsection{Duration variables and cycle}

Given that individuals enter the sample as soon as they satisfy the requirements to claim a pension, we can interpret the significance of the dummy coefficient for duration 1 (g1) as a test for the relevance of becoming entitled to access the retirement benefits ${ }^{26}$. We could expect that if the preference for retiring is high enough, becoming eligible would be a main determinant of the decision to retire, and people will retire as soon as the regulation would entitle them to. The regression results report a non statistically significant coefficient for g1 (Table A 2), so that it can be said that the fact of becoming eligible by itself is not a relevant ground for retirement. The results show also a non-monotonic duration dependence.

We will comment on the interrelation between duration and the effect of some of the covariates when we present the results for the latter.

Early-retirement may result from fluctuations in the economic cycle. Our results show that the propensity to retire is pro-cyclical, so that the hazard retirement rate is higher during macroeconomic expansions, feature that has been observed in other studies about retirement decisions [Montizaan, Cörvers and de Grip (2007)]. A possible explanation of this result could be the fact that asset cycles are highly correlated with the evolution of the business cycle. If people rely on their investments to fund their consumption in retirement, besides what they can get from the retirement pension, they are particularly vulnerable to market downturns. That could be the reason why in periods of economic prosperity, prospective retirees are more optimistic about the evolution of their other sources of income and therefore

25. People from all ages can be low topped, but only people that are 64 or older can receive the maximum pension. 26. See the appendix for a description of these conditions. 
decide to retire earlier. On the other hand, Muñoz (1995), pooling the EPA data, provides evidence that in a recession individuals retire earlier.

\subsection{Age}

In our specification, we also include age dummies to account for differential effects arising from age itself. These dummies should capture the effect of growing older "per se", and not through the different coefficients in the calculation of pension rights that are age dependent. The results show that, even when controlling for eligibility criteria and Social security variables, 65 is a prevailing retirement age.

\subsection{Working status, sector of activity and other labour history related variables}

The activity status prevailing during the year before the decision is taken could be relevant for the retirement hazard. In particular, the sample allows us to distinguish between four labour status: working, receiving unemployment benefits and thus also contributing to Social Security, contributing without working nor perceiving unemployment benefits (special agreement), and not contributing.

The results show that a person working at a particular year has a lower probability of retiring the following year than a person who was not working, even when we condition on social security incentives. They also show that being unemployed the preceding year increases the probability of retiring. Such findings may only reflect the predominance of special early retirement programs that exist for unemployed old people ${ }^{27}$. We also find that the size of these effects varies with age, as can be seen in Figure 2, showing a u-shaped form.

Figure 2 Predicted hazard rates according to previous working status and age

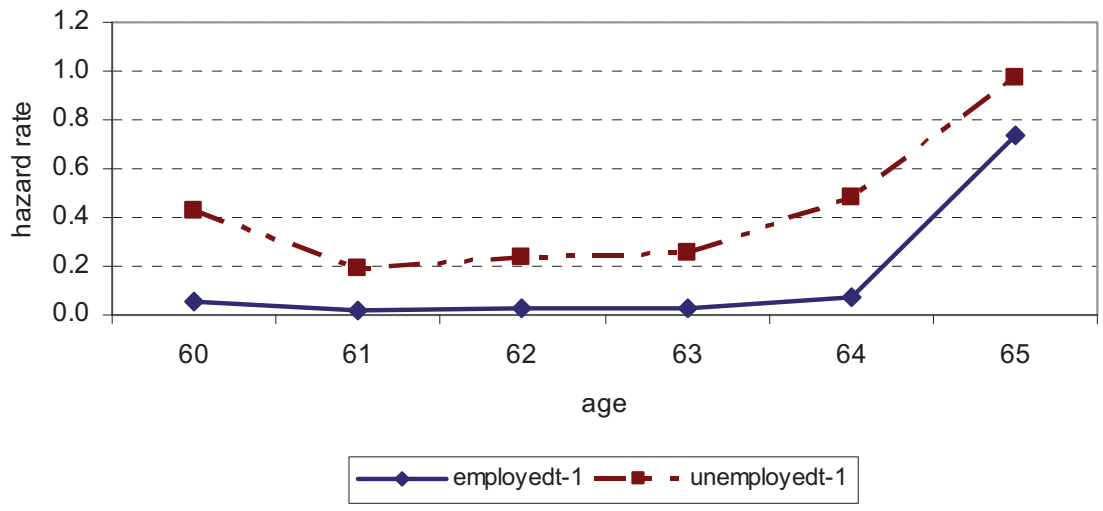

We also include as a covariate the activity sector, which allows us to distinguish between those working in the service sector and those working in the industry sector. The estimated coefficient is, however, not statistically significant, in contrast to other works

27. See García Pérez and Sánchez Martín (2008b) for an analysis of the transitions from unemployment for older people. 
where the sector of activity is found to be playing a role [Conde-Ruiz and García (2004), Blanco (2000), Villagarcía (1995) and Muñoz (1995)].

The next pair of variables try to capture the quality of the labour relations, through the consideration of the number of contracts that have been recorded for a given work history up to the eligibility moment and the average length of these contracts.

The results show that job rotation (proxied by the total number of labour relations that a person has had) has a negative impact on the retirement hazard, impact that fades away as duration increases. The sign of the coefficient suggests that the higher the labour rotation the lower the probability of retiring between 60 and 65 . This result could be in consonance with the findings that workers with a firm-specific training history retire earlier than workers with a general training background [Montizaan, Cörvers and de Grip (2007)].

On the other hand, the average length of the contract seems to play a significant role in the decision to retire only as time unfolds. Although in general, the higher this average the more stable the individual's working life has been, it is not a sophisticated measure of a precarious career as the same average may result from quite different job histories.

\subsection{Individual characteristics and other}

The results obtained for the negative role of higher education on the probability of retiring is in consonance with what is obtained in most empirical work Villagarcía (1995) and Gutiérrez-Domènech (2006)] $]^{28}$. One explanation of such finding may result from the theory that states that low-ability workers are induced to retire early because of the intra-generational redistribution built in early retirement provisions via the utility from leisure [Conde-Ruiz and Galasso (2003)]. The effect of education is reinforced by duration, so that the lower probability of retiring of a higher educated worker is larger the more time it has elapsed since becoming eligible.

As for the health status, the results show a lower hazard for those receiving disability benefits the year before. Such counterintuitive finding may just reflect the fact that those receiving disability benefits, besides having a poorer health, will probably be the ones receiving retirement disability pensions when they turn 65 , the only age in which this type of pensions can be awarded and which we are not including in our analysis.

Receiving public transfers other than unemployment or disability benefits reduces the retirement probability, which may be a consequence of liquidity constraints.

Dummy variables for the region (Autonomous Community) where the worker initially registered are included in the specifications, as a way to capture other differences in the economic environment. Coefficients are not reported but are available under request.

\subsection{Counterfactual Regulation Schemes}

Finally, we have performed a counterfactual exercise with the aim of shedding more light on what these magnitudes are likely to mean in reality, by calculating the effect over estimated retirement probabilities of small changes in the economic incentive mechanisms underlying the Spanish public pension system. The reason for applying only tiny changes to the baseline is to avoid the Lucas' critique, while providing a sensitivity analysis.

28. Muñoz (1995), on the other hand, finds evidence that the education has a quadratic effect, so that those individuals with little or with a lot of studies retire later than those with an intermediate level of education. 
So we have computed the pension wealth that a person would receive under three alternative regulatory schemes, which imply very small changes over the current regulatory situation $^{29}$. We have computed for each individual in the sample the SSW and incentive measures that result from the assumed setting. We then have obtained counterfactual predicted retirement probabilities so that we can compare them with the one predicted under our estimates, which act as a benchmark ${ }^{30}$. In particular, we compute the changes in relation to the population that in the sample are subject to the rules prevailing in 2002. In general terms, each of the three alternative regulatory schemes tries to change only one item in the pension rules.

The first counterfactual scenario, setting A, would consist of an overall reduction in the amount of the pension perceived at all ages. It caps the pension to $96 \%$ of the regulatory base, not allowing individuals to get the $100 \%$ of it at any retirement age ${ }^{31}$. Even if no change in the number of people retiring is produced, such scenario implies a reduction of the pension burden in relation to the benchmark.

Setting B affects mostly the incentive structure as it requires more years of contribution to claim a pension (18 years instead of 15), so that the increase ladder becomes stepper. Moreover, at the age of 66, if the person has more than 35 contributory years, an additional increase in the amount of the pension is added ${ }^{32}$. Under this scenario, it cannot be initially established whether or not the burden rises.

\section{Table 5}

\section{Effects of alternative settings on retirement between ages 60 and $65^{(*)}$}

\begin{tabular}{|c|c|c|c|c|}
\hline & Benchmark & Setting A & Setting B & Setting C \\
\hline Predicted retirement probability ${ }^{(1)}$ & 77.08 & 76.33 & 76.82 & 76.95 \\
\hline Predicted retirement age & 62.92 & 62.93 & 62.93 & 62.92 \\
\hline $\begin{array}{l}\text { Change in number of retired people }{ }^{(1)} \\
\text { by age: }\end{array}$ & - & -1.53 & -1.58 & -0.08 \\
\hline 60 & - & -1.80 & -1.63 & 0.00 \\
\hline 61 & - & -2.45 & -2.09 & 0.00 \\
\hline 62 & - & -2.48 & -2.10 & 0.00 \\
\hline 63 & - & -2.59 & -2.26 & 0.00 \\
\hline 64 & - & -2.06 & -1.90 & 0.00 \\
\hline 65 & - & -0.60 & -1.09 & -0.20 \\
\hline
\end{tabular}

${ }^{(1)}$ In percentage.

${ }^{(*)}$ The effects are estimated for the period beginning in 2002.

Setting A: Capping the pension to $96 \%$ of the Regulatory Base at 35 years of contribution and to $48 \%$ at 15 years of contribution

Setting B: 18 years of contribution to claim a pension. Retiring after 65 implies $3 \%$ increase

Setting C: Retiring after 65 implies $2 \%$ increase and $3 \%$ if 40 years of contribution

29. In general terms the current system is characterised by requiring at least 15 years of contribution and with the pension being at least $50 \%$ of a proxy of gross average lifetime earnings (regulatory base), which raises to $100 \%$ after 35 or more years of contribution See Appendix 2 on legislation for a detailed description of the system.

30. The new probabilities are obtained using the specification in column 1 of Table A 2.

31. Under this scenario, with 15 contributory years the pension amount is only $48 \%$ of the regulatory base. Moreover, up to 25 years of contribution a $3 \%$ increase each year would be added, and from 26 , the increase would be $2 \%$ per year up to $96 \%$ of the regulatory base at 35 or more years of contribution.

32. Under this scenario, there is a $3 \%$ increase up to 25 contributory years, while since then the increase is $3.22 \%$ up to 35 . At 66 with more than 35 years of contribution the increase is also $3.22 \%$. Only $2.6 \%$ of people at 60 have a labour history shorter than 18 years. 
Setting C proposes changes in the short-term incentives to stay beyond 65, in the sense that it only introduces higher retirement benefits for each additional year beyond 65 that an individual remains not retired ${ }^{33}$. If effective, it could raise the burden, not the implementation year but in the mid and long run.

Table 5 shows the computed counterfactual predicted retirement probabilities for these three scenarios, the average predicted retirement age over the age interval 60-65 and the changes in the number of retirees in the same interval and its disaggregation by ages. All the changes analysed result in an extremely mild increase on the average retirement age and a reduction in the number of people who retire between 60 and 65 , which goes from $0.08 \%$ under setting $C$ to $1.6 \%$ under setting $B$.

We obtain that under the first two scenarios, the retirement rates of all ages are affected by the proposed change and that the effects are increasing with age up to 63, when the largest impact is recorded. The smallest effect is at 65 , reflecting, probably, how this age is regarded as normal retirement age.

The fact that under setting $C$ there is a null impact on the probability of retiring between 60 and 64 with respect to the benchmark results from the specification chosen to compute the effects, that only reflects the impact of changes in SSA. However, the low incidence of the long term incentive (peak value) on the decision results in a very similar figure when the specification with the PV variable is chosen, instead. In any case, the decrease in the number of people that choose to retire at 65 so as to retire at a later age is rather small $(0.20 \%)$, as only the incentive changes, but not the social security wealth at that age ${ }^{34}$.

33. It reproduces part of the changes introduced by the "Acuerdo sobre Medidas en Materia de Seguridad Social", of 13 July 2006, which were implemented two years later. In particular, at 66 with at least 35 years of contribution a 2\% increase in the pension is added, raising it to $3 \%$ for those individuals with at least 40 years of contribution.

34. In fact, those whose entire contributory life is below 35 years experience a reduction in the amount they perceive at 65 in relation to the benchmark. 


\section{Conclusions}

There is some agreement that early retirement provisions account for a large proportion of the drop in the labour force participation of elderly workers that had been observed in Spain in the nineties. This paper aims at quantifying the impact of these provisions under the Spanish Social Security System in the early 2000.

We have gathered evidence that, in general, the economic incentives stemming from Social Security regulations on old age pensions in Spain seem to have the expected effect on retirement. We find that the present value of the future flow of pensions has a positive impact on the probability of retiring, with larger pensions shortening the span between becoming eligible for retirement and actually claiming the retirement pension. Therefore, all measures taken to reduce the present value of such flow at early ages may have the desired effect of reducing early retirement.

Moreover, it seems that the built-in incentives in the system not to retire early have a non negligible effect on old-age retirement, so that they are effective in retaining people. The higher flow of pensions that workers receive for staying at work one additional year compensate both the loss of leisure that they experience for the additional year that they keep contributing and the wage and salary they perceive at work.

We also found that the new scheme implemented since 2002 has reduced the probability of retiring at each age, in spite of the fact that the substitution effects captured through the incentives measures seem to have reduced their incidence on retirement decisions. We also found some evidence of a more myopic behaviour of workers as regards social security incentives. The changes in the regulation that have taken place may explain such results.

Therefore, our results suggest that, from a policy perspective, reinforcing the economic incentives in the system would reduce early retirement. However, any new change in the incentive structure of pensions should take into account the longer work histories that younger people have, when becoming eligible. In fact, the counterfactual results show that a small change in the incentive structure has a small impact on the number of people retiring. In particular, it seems that to increase the number of people staying beyond 65 requires more than a tiny push. Therefore, a combination of economic incentives with other institutional constraints would be necessary to effectively increase the retirement age.

Finally, as to the impact of these changes on the Social Security accounts, our results show that minor changes in the rules that define the amount to perceive at each age and in relation to the years effectively contributed may have a positive impact on the accounts, through its impact on the probability to retire at each age. However, this might not be enough to address the consequences of an ageing population. Thus, from this perspective, amendments in retirement rules could be oriented to link the possibility of retiring and the benefit rights not only to contributive efforts to, but also to life expectancy. 


\section{REFERENCES}

ALBA, A. (1997). Labour Market Participation and Transitions of Older Workers in Spain, Working Paper N. ${ }^{\circ}$ 97-39, Universidad Carlos III.

ARGIMÓN, I., and C. I. GONZÁLEZ (2006). "La Muestra Continua de Vidas Laborales de la Seguridad Social”, Boletín Económico, mayo, Banco de España.

ARGIMÓN, I., C. I. GONZÁLEZ and R. VEGAS (2007). "La situación laboral en las edades próximas a la jubilación. Una explotación de la Muestra Continua de Vidas Laborales", Boletín Económico, abril, Banco de España.

BLANCO, A. (2000). The decision of early retirement in Spain, FEDEA, EEE 76.

BLUNDELL, R., C. MEGHIR and S. SMITH (2002). "Pension incentives and the pattern of early retirement", The Economic Journal, 112 pp. 153-170.

BOLDRIN, M., and S. JIMÉNEZ-MARTíN (2002). Evaluating Spanish pension expenditure under alternative reform scenarios, UPF Working Paper 652.

BOLDRIN, M., S. JIMÉNEZ-MARTÍN and F. PERACCHI (1999). "Social Security and retirement in Spain", in J. Gruber and D. Wise (eds.), Social Security programs around the world, University of Chicago Press, Chicago, pp. 305-353.

— (2004). "Micro-modelling of retirement behaviour in Spain", in J. Gruber and D. Wise (eds.), Social Security programs and retirement around the world. Micro-estimation, University of Chicago Press, Chicago, pp. 499-578.

BOVER, O., M. ARELLANO and S. BENTOLILA (2002). "Unemployment duration, benefit duration and the business cycle" The Economic Journal, 112, April, pp. 223-265.

BURTLESS, G. (1986). "Social Security, unanticipated benefit increases and the timing of retirement", The Review of Economic Studies, 53, pp. 781-805c.

CAIRÓ, I. (2007) "An empirical analysis of retirement behaviour in Spain: Partial vs. Full Retirement". Mimeo.

COILE, C., and J. GRUBER (2000). Social Security incentives for retirement, NBER DP 7651, April.

CONDE-RUIZ, J. I., and V. GALASSO (2003). "Early retirement", Review of Economic Dynamics, 2, pp. 12-36.

CONDE-RUIZ, J. I., and E. GARCÍA (2004). Demografía y empleo de los trabajadores próximos a la jubilación en Cataluña, FEDEA Documento de Trabajo 2004-29.

DIAMOND, P., and J. GRUBER (1999). "Social security and retirement in the U.S.", in J. Gruber and D. Wise (eds.) Social Security programs and retirement around the world, University of Chicago Press, Chicago.

DÍAZ-GIMÉNEZ, J., and J. DÍAZ-SAAVEDRA (2008). "Delaying retirement in Spain", forthcoming in Review of Economic Dynamics.

GARCÍA-PÉREZ, J. I., and A. R. SÁNCHEZ-MARTíN (2008a). Social Security and the search behaviour of workers approaching retirement, Working Paper, Econ 08 03, Universidad Pablo Olavide.

- (2008b). "Jubilación y búsqueda de empleo a edades avanzadas", Actual, 33, Fundación Centro de Estudios Avanzados, Centro de Estudios Andaluces.

GRUBER. J., and D. WISE (1999). Social Security programs around the world, University of Chicago Press, Chicago.

- (2004). Social Security programs and retirement around the world. Micro-estimation, University of Chicago Press, Chicago.

GUTIÉRREZ-DOMĖNECH, M. (2006). "The employment of older workers", Working Paper No. 04/2006, la Caixa.

HAKOLA, T. (2002). "Economic incentives and labour market transitions of the aged Finnish workforce", VATT Research Report.

IMROHOROGLU, A., S. IMROHOROGLU and D. H. JOINES (1999). "Computing models of social security», in R. Marimón and A. Scott (eds.), Computational methods for the study of dynamic economies.

JIMÉNEZ-MARTÍN, S. (2006). "Evaluating the labor supply effects of alternative reforms of the Spanish pension system", Moneda y Crédito, 222, pp. 271-312.

JIMÉNEZ-MARTÍN, S., and A. R. SÁNCHEZ (2000). "Incentivos y reglas de jubilación en España", Cuadernos Económicos, ICE, N. ${ }^{\circ}$ 65, pp. 45-88.

- (2006). An evaluation of the life-cycle effects of minimum pensions on retirement behaviour: Extended Version, Working Papers 06.23, Universidad Pablo de Olavide, Departamento de Economía.

JIMENO, J., J. ROJAS and S. PUENTE (2006). Modelling the impact ageing in Social Security expenditures, Documentos Ocasionales, N. ${ }^{\circ} 0601$, Banco de España.

LABEAGA, J. M. (2008). Estudios sobre las decisiones de retiro, la sostenibilidad del sistema de pensiones en España y la viabilidad financiera del Sistema Nacional de Dependencia, Colección Estudios Económicos 04-08, Cátedra Nuevos Consumidores/FEDEA-BBVA.

MARTÍNEZ, F. (1999). Historiales de la Seguridad Social, mimeo, Universidad Carlos III.

MONTIZAAN, R., F. CÖRVERS and A. DE GRIP (2007). Training and early retirement, Research Centre for Education and the Labour Market, ROA-RM-2007/3, July 07, The Netherlands.

MUÑOZ, J. (1995). Un análisis de los determinantes de la edad de jubilación mediante modelos de duración, Documento de Trabajo 9523, CEMFI.

NORTON, E., H. WANG and C. Al (2004). "Computing interaction effects and standard errors in logit and probit models", The Stata Journal, 4, N. ${ }^{\circ}$, pp. 154-167.

PRIETO, J., D. ROMERO and S. ÁLVAREZ (2002). Estado de salud y participación laboral de las personas mayores, Papeles de Trabajo 15/02, Instituto de Estudios Fiscales, Madrid.

SAMWICK, A. (1998). "New evidence on pensions, social security, and the timing of retirement", Journal of Public Economics, 70, pp. 207-236.

SÁNCHEZ MARTíN, A. R. (2003). Jubilación endógena y sistema público de pensiones en España, Universidad Carlos III WE 072515. 
SÁNCHEZ MARTÍN, A. R. (2005). Endogenous retirement and public pension system reform in Spain, mimeo.

SEGURIDAD SOCIAL (2006). La Muestra Continua de Vidas Laborales, Colección informes y estudios, Serie Seguridad Social N. ${ }^{\circ} 24$

SPATARO, L. (2002). New tools in micro-modelling retirement decisions: overview and applications to the Italian case, WP 28/2, Centre for Research on Pensions and welfare policies.

- (2005). "Social security incentives and retirement decisions in Italy: an empirical insight", Research in Economics, 59; pp. 223-256

STOCK, J. H., and D. A. WISE (1990). "Pensions, the option value of work and retirement", Econometrica, 58, pp. $1151-1180$

UTRILLA DE LA HOZ, A., and Y. UBAGO (2005). Efectos redistributivos del sistema de pensiones de la Seguridad Social y factores determinantes de la elección de la edad de jubilación. Un análisis por Comunidades Autónomas, Papeles de Trabajo 3/05, Instituto de Estudios Fiscales, Madrid.

VILLAGARCÍA, T. (1995). "Análisis econométrico del tránsito a la jubilación par trabajadores en edad avanzada", Investigaciones Económicas, Vol. XIX(1), pp. 65-81. 


\section{DATA}

This appendix contains the definition of the variables included in the different specifications. As it has already been mentioned in the text, the main data source is the Muestra Continua de Vidas Laborales 2006 (MCVL 2006), a sample of administrative data gathered by the Social Security Department.

The subsample used includes the available information on men who have contributed to social security at least once in their lifetime, have not collected an old age pension before 1997, and who were born between 1936 and 1946, so that in 2006 they were between 60 and 70 years old. Moreover, we restrict it to those men whose longest contributory relationship with the Social Security took place in the General Regime, the scheme that covers most workers and whose description can be found in the following appendix on legislation. We also drop those individuals who have collected an old pension after 1997, but whose eligibility to access a retirement pension, in terms of having at least fifteen contributory years, could not be proved with the available data, as a pension could not be estimated for them ${ }^{35}$. The final subsample is composed of 35,853 individuals. The main statistics for each variable is presented in Table A1.

\section{Economic Incentive Variables}

To calculate the Social Security benefits to which individuals in our sample are entitled, we make use of the Social Security covered earnings histories of individual in the MCVL 2006.

SSW it : Value of Social Security Wealth of individual i at time t, at 2006 prices:

$$
\operatorname{SSW}(r)_{i t}=\sum_{s=t}^{s=L}\left[B_{i}(s, r)\left[p(s \mid t)_{i} /\left(1+\rho_{i}\right)^{s-t}\right]\right]
$$

indicates Social Security Wealth at time $t$ (at age $t$ ) if retiring at age $r, L$ is the maximum life length, $B_{i}(s, r)$ is the pension benefit in period $s$ (at age $s$ ) if retiring at $r, p(s \mid r)$ is the conditional probability of an individual at time t to be alive at time $s$ where $s>r, \rho_{i}$ is the individual discount rate.

To calculate the pension we make use of data on covered earnings and from it we have built the Regulatory Base which has been computed as the regulation establishes. The minimum base that has been used to complete job careers has been the one corresponding to contributory group 5, senior administrative ("oficial administrativo"), the group with the largest volume of population. On the other hand, the maximum base has been taken to be the one corresponding to group 1, Engineers and Graduates ("Ingenieros y Licenciados"), the group with the highest base for all the years. The maximum life length $(L)$ has been taken to be 98 years; $\rho_{i}$, the individual discount rate is assumed to be fixed at $3 \%, p(s \mid r)$, the conditional probability of an individual aged $r$ to be alive at age $s$, has been taken from the National Statistics Institute (INE) demographic projections scenario 2, based upon 2001 Census data and pensions are assumed to increase $2 \%$ yearly

35. The administrative nature of the data source explains that a limited number of individuals had to be deleted from the sample as the available information for them did not seem consistent. 
from 2006. Minimum and maximum pensions are applied and the minimum one corresponds to a worker with a dependent spouse.

In order to calculate the different incentive measures, we need to project SSW for the future. Two different situations arise, depending on the age of the individual and whether or not he has retired. For those that are not 66 before 2006, we need to project their pension and their SSW beyond this year. To do so, we assume that their salary and, therefore, their contributory base will be increasing at a $2 \%$ rate every year. For those that have retired before 2006, we project their salaries for the years before 2006 assuming that they keep the purchasing power of their last observed salary (or the following one), so that the contributory base increases by the same amount as the December over December $\mathrm{CPI}^{36}$.

SSA it : The accrual rate,

$$
\operatorname{SSA}(r)_{\text {it }}=1 /\left(1+\rho_{\mathrm{i}}\right) \operatorname{SSW}(r+1)_{\text {it }}-\operatorname{SSW}(r)_{\text {it }}
$$

and we let

$$
\operatorname{SSW}(r+1)_{i t}=\frac{\operatorname{SSW}(r+1)_{i t+1}}{\left(1+\Pi_{t}\right)}
$$

A limitation of this index is that it does not take into account the comparison that the individual can make between pension benefits and the level of his/her income. It could be argued that the leisure preference is such that wages can fully compensate for the forgone leisure enjoyment from postponing retirement.

$\mathbf{P V}_{\text {it }}$ : Peak Value computed between the ages of 60 and 65 is defined as,

$$
\begin{aligned}
& P V_{i}(r)=\max \left(S S W(r, r+1)_{i}, S S W(r, r+2) r_{i}, S S W(r, r+3)_{i} \ldots, S S W(r, 66)_{i}\right) \\
& =S S A_{i}, \text { otherwise }
\end{aligned}
$$

where

$\operatorname{SSW}(r, r+j)=\operatorname{SSW}(r+j) /(1+\rho)^{j}-\operatorname{SSW}(r)$

We follow Coile and Gruber (2000) and restrict the peak value to be equal to the accrual rate, if the individual works beyond the highest value for his social security wealth ${ }^{37}$.

$\mathbf{R R}_{\mathrm{it}}$ : Replacement rate, $R R_{i}(r)$ is the ratio of the expected pension benefits $B_{i}(r)$ at time $\mathrm{t}$ over wages $w_{i}(r)$ perceived at time $\mathrm{t}-1$ for individual $i$ at age $r$, if the person retires at age $r$.

36. Alternatively, we could have taken the average increase in observed national accounts data for compensation of employees.

37. They also normalize the peak value by the expected stream of wages over the period between the maximum year and the current year. Hence their actual index measures the benefits of continued work relative to the social security wealth earnings in the same period. They call this measure the tax/subsidy rate. This normalization can also be made to the accrual measure. 


$$
R_{i}(r)=E_{r}\left(B_{i}(r) / w_{i}(r)\right)
$$

where $\mathrm{E}$ is the expectation operator.

\section{Other variables}

failurejubi it : dummy variable that takes value 1 if the person retires at time $t$ and 0 otherwise. It is the dependent variable.

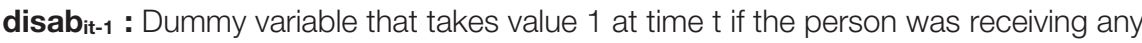
disability benefit while he was a year younger (at time t-1) and zero, otherwise.

univ $_{\mathbf{i}}$ : dummy variable that takes value 1 if the contributory group ("grupo de cotización") of the longest contributory relationship with the Social Security system is the one with the highest academic qualifications (group 1: "Engineers and Graduates"), and zero, otherwise.

numrel $_{\mathbf{i}}$ : number of contributory labour relations that have been recorded by the Social Security before becoming entitled to an old age pension and that include those involving the perception of unemployment benefits.

Regional Government (Comunidad Autónoma) where the worker initially registered: Group of 19 dummy variables, each one corresponding to a CA, plus one for Ceuta and one for Melilla, that records the initial worker's registration. (Ilccaa-)

$\operatorname{serv}_{\mathbf{i}}$ : Dummy variable that takes value 1 if the longest job a person has held has taken place in the following CNAE sector classifications: Trade (50 to 52), Restoration (Hostelería) (55), Transport (60 to 64), other services, including education y health (65 to 67, 70 to $74,80,85$ and 90$)$.

$\mathbf{u}_{\mathrm{it}-1}$ : Dummy variable that takes value 1 at time $\mathrm{t}$ if the person was receiving unemployment benefits ${ }^{38}$, either as a subsidy or a contributory transfer, while he was a year younger (at time t-1), and zero, otherwise.

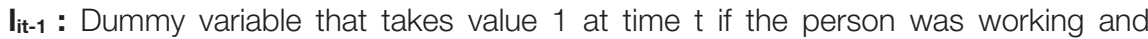
contributing to Social Security while he was a year younger (at time t-1), and value zero, otherwise.

g_kit : Dummy variables that take value 1 if the person is at time $t$ in the $k$-th period decision and cero otherwise, where $k=[1,6]$. That is, $\mathbf{g} \_\mathbf{k}$ takes value 1 if the value of the length of the spell from the year the person becomes entitled to a retirement pension is $\mathbf{k}$.

age_k $\mathbf{k}_{\text {it }}$ : Dummy variables that take value 1 if the person is $k$ years old at time $t$ and cero otherwise, where $k=[60,65]$.

cycle $_{\mathbf{t}}$ : Spanish GDP real growth rate (for years 1997 to 2006).

38. It corresponds to the people whose relationship with Social Security is coded as a TRL 751-756 in the administrative files. 
r2002: Dummy variable that takes value 1 if the year of the observation is greater than 2001.

otherben $_{\mathrm{it-1}}$ : Dummy variable that takes value 1 at time $t$ if the person was receiving any Social Security benefit other than disability, old age or unemployment while he was a year younger (at time t-1) and zero, otherwise.

meanlengthı : average number of years per spell that the individual i has had before becoming entitled to a pension.

t: trend variable. 


\section{APPENDIX 2}

\section{LEGISLATION}

\section{The institutional framework}

The labour-market based social security is mandatory for workers in Spain. Old-age public pensions are mainly provided through three different schemes: General Social Security scheme [Régimen General de la Seguridad Social (RGSS)], Special Social Security Regimes [Regímenes Especiales de la Seguridad Social (RESS)] and government employees scheme [Régimen de Clases Pasivas (RCP)] ${ }^{39}$. Around $72 \%$ of social security contributions are obtained from the RGSS. The pension regulations for RESS, within which the self-employed are assigned, and RCP do not, in general, allow for early retirement, so that the focus of the analysis will be on the RGSS.

The main changes that have taken place in Social Security regulation in recent years that affect the period covered by the sample correspond to the reforms introduced in 1997 and 2002 in relation to the framework set in $1985 .{ }^{40}$

The normal retirement age in Spain, that is the age when a person becomes eligible for the full pension benefit, is 65. In fact, in some sectors retirement at sixty-five has been compulsory for some years. However, since 2002, incentives have been built in the regulation so as to promote retirement beyond the age of $65^{41}$. Early retirement is possible from the age of 60 , under some strict conditions that are detailed below and that imply a reduction in the amount of the pension to be perceived that is defined by a reduction coefficient.

\section{Entitlement criteria for RGSS}

A payroll tax defined for both employers and employees and levied on earnings, with a minimum contribution and a maximum pensionable earning, finances the Social Security System.

Up to 1997 only 8 contributory years were required to be entitled to a retirement pension. The change introduced in 1997 set a timetable to extend this period to fifteen years, one every year, so that in 2002, 15 years were required to be able to receive a pension at the age of 65, the ordinary retirement age. An additional requirement introduced in 1997 was that two of these contributed years had to have taken place during the last eight years.

As for early retirement before the age of 65 there are three different cases ${ }^{42}$ :

39. The RGSS and RESS are administered and managed by the Social Security as a joint pay-as-you-go system. The RCP is administered and managed by the Central Government.

40. In particular, up to 2002, pension regulations required total or substantial withdrawal from any form of employment requiring affiliation to the Social Security System to be able to perceive an old-age pension. In 2002, partial retirement was regulated, so that employment and old-age pensions could be simultaneously enjoyed, while the mandatory retirement age at 65 was effectively abolished. In 2006 a new agreement among government, trade unions and employers' associations was reached, but with limited impact. Ley 40/2007, de 4 de diciembre, de medidas en materia de Seguridad Social.

41. The regulation increased the amount of the pension to be received if the worker remained employed while the payment of social contributions by employers and employees with indefinite-term contacts were waived.

42. Regulation also allows for early retirement for special professions, especially those involving dangerous or unhealthy activities or some instances of those affected by industrial restructuring regulated by special legislation. Moreover, as it has already been mentioned, a new regulation came into force in 2002 allowing for partial retirement that can be simultaneously enjoyed with a part-time job. Workers can partially retire starting at the age of 60 if the firm replaces the retiree with another worker (relief contract) to compensate for the retiree's reduction in work-time. 
On the one hand, those who, before January 1, 1967, contributed to the labour mutual funds system that preceded the current Social Security system are entitled to retire from the age of 60 if the total contributory years are at least 15.

For those whose initial contribution year dates from after 1967 and only since the 2002 amendment, the earliest retirement age is 61. For them, the minimum number of contributory years amounts to 30. Moreover, in order to be able to claim the pension, they have to have spent at least six months involuntarily unemployed and registered as job seekers in the Public Employment Service Offices, immediately preceding the claim. Years spent unemployed and receiving unemployment benefits add as contributory years towards an old-age pension ${ }^{43}$.

Retiring at the age of 64 is also possible and is subject to different rules: from 2002 no previous period of unemployment is required, but just the minimum 15 contributory years. However, in this case, the firm needs to hire another worker for a minimum period of a year (substitution contract) to replace the retiree, if full benefits (as at the age of 65) are to be guaranteed.

The database does not provide information about contributions dating from before the seventies. On the other hand, all men born between 1936 and 1946 could potentially have been working by 1967, as the youngest would have started working at the age of 21 . Therefore, the assumption in the empirical part is that all people in the sample contributed to the labour mutual funds system, so that they only require 15 years of contribution to be entitled to retire ${ }^{44}$. In fact, in our sample $34 \%$ of those we observe retiring, do so at 60 years of age.

\section{The pension amount}

The actual level of the old age pension is defined by the interaction of different elements. On the one hand, the Regulatory Base (Base reguladora, BR) that defines the amount upon which to calculate the pension rights is directly related to wages perceived, but subject to lower and upper caps ${ }^{45}$. The minimum and maximum contributory periods to be included in its calculation and the inflation correction to obtain its present value are regulatory defined. Reduction coefficients for early retirement and for less than 35 years of contribution are also defined ${ }^{46}$. Minimum and maximum pensions are yearly defined and depend on marital status and number of dependents of the person receiving the benefit. Pensions are indexed by the Consumer Price Index. Up to 2002, any additional year contributed beyond 35 did not add to the amount of pension received.

A person retiring between 1985 and 1996 with at least 15 contributory years at year $t$ had a regulatory base defined as:

$$
B R_{t}=\frac{1}{112}\left(\sum_{j=1}^{24} w_{t-j}+\sum_{j=25}^{96} w_{t-j} \frac{I_{t-25}}{I_{t-j}}\right)
$$

43. In fact, unemployed workers aged 52 and older can receive unemployment benefits that turn into subsidies until they are eligible for early or ordinary retirement.

44. We also find that $40 \%$ of people in the sample who retire do so with less than 30 registered years of contribution. 45. Different caps have been in place for different types of workers depending on their group of contribution (grupo de cotización) associated with the type of job and education level.

46. As it has already been mentioned, there is a special treatment for those that contributed to the system before 1967 (mutual funds contributors or "mutualistas"). 
where $\mathrm{w}_{\mathrm{t}-\mathrm{j}}$ are covered earnings for the jth month before retiring at $\mathrm{t}$ and $\mathrm{I}_{\mathrm{t}-\mathrm{j}}$ is the price index for the jth month before retirement ${ }^{47}$, so that only eight years are taken into account to define $B R$.

Since 2002, the contributory base is defined as:

$$
B R_{t}=\frac{1}{210}\left(\sum_{j=1}^{24} w_{t-j}+\sum_{j=25}^{180} w_{t-j} \frac{I_{t-25}}{I_{t-j}}\right)
$$

so that 15 years are taken into account. A transitory period was set from 1997 to 2002 so that a one year increase in the years considered in the indexed part of the weighted average was included per year, so that in 2002 the fifteen years were finally accounted for ${ }^{48}$.

The relation between the first monthly pension received at time $t\left(B_{t}\right)$ and the regulatory base $\left(B R_{t}\right)$ calculated at $t$ can be expressed as:

$$
B_{t}=\alpha_{n t}^{T} \cdot B R_{t}
$$

where $\alpha_{n t}{ }^{T}=\alpha_{n t}{ }^{y} \alpha_{n t}{ }^{a}$, so that $\alpha_{n t}{ }^{y}$ depends only on contributory years ( $n$ ), and $\alpha_{n t}{ }^{a}$ depends on the age of retirement. If retirement age is equal or larger than 65 then, and up to 1997 , $\alpha_{n t}{ }^{a}=1$ and $\alpha_{n t}{ }^{T}$ is expressed as:

$$
\alpha_{n t}^{T}=\left\{\begin{array}{lc}
0 & \text { if } n<15 \\
0.6+0.02(n-15), & \text { if } 15 \leq n<35 \\
1, & \text { if } 35 \leq n
\end{array}\right.
$$

The reform introduced in 1997 modified the number of years to define the contributory base and the substitution rate $\left(\boldsymbol{\alpha}_{n}^{T}\right)$ if age of retirement was equal or larger than 65 , so that:

$$
\alpha_{n t}^{T}=\left\{\begin{array}{lc}
0, & \text { if } n<15 \\
0 \cdot 5+0.03(n-15), & \text { if } 15 \leq n<25 \\
0 \cdot 8+0.02(n-25), & \text { if } 25 \leq n<35 \\
1 & \text { if } 35 \leq n
\end{array}\right.
$$

The new scheme thus implies a more progressive approach to full benefits.

For early retirement, regulation also sets a penalization system linked to age. Mutualistas that retire early are subject to a reduction coefficient equivalent to $8 \%$ for each year in advance of 65 that he/she retires, so that $\alpha_{t}^{a}=1-0.08(65-r)$ where $r>=60$. The 1997 reform reduced the reduction coefficient to $7 \%$ for those with more than 40

47. It is divided by 112 as pensions are paid in fourteen annual instalments.

48. As social contributions are paid 14 months a year, the effective number of years taken into account to compute the regulatory base is 6.8 up to 1997 and 12.9 since then. The 2006 agreement proposes to rise the effective contributory years to 15 , without taking into account the 14 monthly payments. 
contributory years, when claiming the pension. This coefficient should be jointly applied with the one corresponding to contributory years.

The 2002 reform changed the penalization mechanism, so as to make the age coefficient $\left(\alpha_{t}^{a}\right)$ more linked to the number of contributed years, so that:

$$
\alpha_{n t}^{a}=\left\{\begin{array} { l l } 
{ 0 } & { \text { if } r < 6 1 } \\
{ 1 - k ( 6 5 - r ) , } & { \text { if } 6 1 \leq r < 6 5 \text { where } } \\
{ 1 , } & { \text { if } r \geq 6 5 }
\end{array} \quad k \left\{\begin{array}{l}
0.08 \text { if } n=30 \\
0.075 \text { if } 31 \leq n \leq 34 \\
0.07 \text { if } 35 \leq n \leq 37 \\
0.065 \text { if } 38 \leq n \leq 39 \\
0.06 \text { if } n \geq 40
\end{array}\right.\right.
$$

where $r$ is retirement age.

Moreover, it introduced a premium for late retirement, so that the pension was increased by $2 \%$ per additional year if the worker credited more than 35 years of contribution ${ }^{49}$ :

$$
\alpha_{n}^{T}=1+0.02(r-65) \text { if } r>65 \text { and } n \geq 35
$$

49. The 2006 agreement proposed raising the premium to $3 \%$ for those with more than 40 contributory years. The partial retirement regulation introduced with the 2002 reform, established that no correction coefficient for age would be used for those claiming this type of pension. The reform agreed in 2006 aims at rationalizing this type of retirement, requiring six years of seniority in the firm before retiring, 30 contributory years (instead of the current 15), and changing the maximum and minimum labour day reduction to $75 \%$ and $25 \%$, respectively from the current $85 \%$ to $15 \%$. Full implementation will be in four years time. 
Table A 1

Descriptive values. Sample of

men born between 1936 and 1946, having worked in the General Regimen, with a relation with the Social Security in 2006

\begin{tabular}{|c|c|c|c|c|c|c|c|c|c|}
\hline & \multicolumn{3}{|c|}{ All period considered } & \multicolumn{3}{|c|}{ Before 2002} & \multicolumn{3}{|c|}{ After 2002} \\
\hline & median & mean & s.d. & median & mean & s.d. & median & mean & s.d. \\
\hline $\operatorname{SSW}_{t}^{(1)}$ & 199.30 & 222.50 & 96.83 & 195.83 & 211.84 & 87.02 & 201.35 & 228.17 & 101.21 \\
\hline $\operatorname{SSA}_{t}^{(1)}$ & 6.89 & 6.73 & 12.95 & 10.12 & 9.79 & 12.20 & 4.97 & 5.09 & 13.04 \\
\hline$P V_{t}^{(1)}$ & 12.65 & 18.84 & 26.73 & 21.68 & 26.77 & 28.03 & 8.32 & 14.63 & 25.01 \\
\hline $\mathbf{R R}_{\mathrm{t}}^{(2)}$ & 57.61 & 67.36 & 35.50 & 50.77 & 57.61 & 26.56 & 61.93 & 72.55 & 38.45 \\
\hline$I_{t-1}^{(2)}$ & & 57.49 & & & 62.67 & & & 54.74 & \\
\hline$u_{t-1}{ }^{(2)}$ & & 24.28 & & & 27.54 & & & 22.55 & \\
\hline numrel & & 10.770 & 25.866 & & 9.547 & 19.763 & & 11.420 & 28.565 \\
\hline meanlenght $^{(3)}$ & & 7.237 & 7.243 & & 7.763 & 7.436 & & 6.957 & 7.122 \\
\hline time since eligible ${ }^{(3)}$ & & 2.677 & 1.565 & & 2.275 & 1.390 & & 2.892 & 1.609 \\
\hline univ & & 0.106 & 0.307 & & 0.101 & 0.302 & & 0.108 & 0.310 \\
\hline serv & & 0.364 & 0.481 & & 0.356 & 0.479 & & 0.367 & 0.482 \\
\hline disab & & 0.126 & 0.332 & & 0.024 & 0.152 & & 0.181 & 0.385 \\
\hline otherben & & 0.134 & 0.341 & & 0.030 & 0.172 & & 0.190 & 0.392 \\
\hline low60 & & 0.086 & 0.281 & & 0.101 & 0.302 & & 0.078 & 0.268 \\
\hline low61 & & 0.047 & 0.211 & & 0.034 & 0.181 & & 0.053 & 0.224 \\
\hline low62 & & 0.029 & 0.168 & & 0.015 & 0.123 & & 0.036 & 0.187 \\
\hline low63 & & 0.018 & 0.134 & & 0.008 & 0.091 & & 0.024 & 0.152 \\
\hline low64 & & 0.011 & 0.104 & & 0.005 & 0.067 & & 0.014 & 0.120 \\
\hline low65 & & 0.008 & 0.086 & & 0.003 & 0.053 & & 0.010 & 0.100 \\
\hline top64 & & 0.001 & 0.037 & & 0.001 & 0.025 & & 0.002 & 0.042 \\
\hline top65 & & 0.003 & 0.058 & & 0.001 & 0.034 & & 0.005 & 0.067 \\
\hline age61 & & 0.219 & 0.413 & & 0.236 & 0.425 & & 0.209 & 0.407 \\
\hline age62 & & 0.175 & 0.380 & & 0.158 & 0.365 & & 0.184 & 0.387 \\
\hline age63 & & 0.135 & 0.342 & & 0.110 & 0.313 & & 0.148 & 0.355 \\
\hline age64 & & 0.100 & 0.300 & & 0.068 & 0.252 & & 0.118 & 0.322 \\
\hline age65 & & 0.065 & 0.246 & & 0.027 & 0.162 & & 0.085 & 0.278 \\
\hline cycle $^{(4)}$ & & 3.667 & 0.679 & & 4.262 & 0.688 & & 3.350 & 0.406 \\
\hline r2002 & & 0.653 & 0.476 & & 0.000 & 0.000 & & 1.000 & 0.000 \\
\hline
\end{tabular}


Table A 2

Logit estimates of the effects of pension incentives on retirement behaviour between 60 and 65 years of age. Males born between 1936 and 1946 , having worked in the General Regime with a relation with the Social Security in 2006(*)

\begin{tabular}{|c|c|c|c|c|c|}
\hline \multicolumn{2}{|c|}{ MODEL A } & \multicolumn{2}{|c|}{ MODEL B } & \multicolumn{2}{|c|}{ MODEL C } \\
\hline ACCRUAL & PEAK VALUE & ACCRUAL & PEAK VALUE & ACCRUAL & PEAK VALUE \\
\hline LR $\operatorname{chi} 2(45)=38014.62$ & LR chi2(49)=38187.03 & LR chi2(56) $=38597.09$ & LR chi2(45) $=38030.83$ & LR chi2(49) $=38213.54$ & LR chi2(56) $=38607.93$ \\
\hline Pseudo R2 $=0.365$ & Pseudo R2=0.367 & Pseudo R2=0.371 & Pseudo R2=0.365 & Pseudo $\mathrm{R} 2=0.367$ & Pseudo R2=0.371 \\
\hline
\end{tabular}

115.532 number of observations

\begin{tabular}{|c|c|c|c|c|c|c|}
\hline \multicolumn{7}{|c|}{ ECONOMIC INCENTIVES AND REGULATION } \\
\hline ssw $_{t}$ & $\begin{array}{c}2.979 \\
(23.08)^{\star \star \star}\end{array}$ & $\begin{array}{c}2.969 \\
(23.31)^{\star * *}\end{array}$ & $\begin{array}{c}2.462 \\
(11.69)^{\star \star \star}\end{array}$ & $\begin{array}{c}2.401 \\
(11.81)^{\star \star \star \star}\end{array}$ & $\begin{array}{c}2.322 \\
(10.78)^{\star \star \star *}\end{array}$ & $\begin{array}{c}2.289 \\
(10.83)^{\star * * *}\end{array}$ \\
\hline SSA $_{t}$ & $\begin{array}{c}-7.993 \\
(-7.07)^{\star \star \star}\end{array}$ & & $\begin{array}{c}-12.941 \\
(-7.78)^{\star \star \star}\end{array}$ & & $\begin{array}{c}-10.510 \\
(-5.69)^{\star \star \star *}\end{array}$ & \\
\hline $\mathrm{PV}_{\mathrm{t}}$ & & $\begin{array}{c}-4.284 \\
(-8.11)^{\star * *}\end{array}$ & & $\begin{array}{c}-6.730 \\
(-9.26)^{\star \star * *}\end{array}$ & & $\begin{array}{c}-5.363 \\
(-6.92)^{\star * \star}\end{array}$ \\
\hline $\mathbf{R R}_{\mathrm{t}}$ & $\begin{array}{c}\mathbf{0 . 0 4 6} \\
(1.2)\end{array}$ & $\begin{array}{l}\mathbf{0 . 0 4 3} \\
(1.14)\end{array}$ & $\begin{array}{l}-0.083 \\
(-1.25)\end{array}$ & $\begin{array}{c}-0.144 \\
(-2.14)^{\star}\end{array}$ & $\begin{array}{l}-0.085 \\
(-1.28)\end{array}$ & $\begin{array}{c}-0.139 \\
(-2.06)^{\star}\end{array}$ \\
\hline $\mathrm{SSW}_{\mathrm{t}}{ }^{*} \mathrm{r} 2002$ & & & $\begin{array}{c}1.109 \\
(4.76)^{\star \star *}\end{array}$ & $\begin{array}{c}1.166 \\
(5.16)^{\star \star \star}\end{array}$ & $\begin{array}{c}1.272 \\
(5.48)^{\star \star \star \star}\end{array}$ & $\begin{array}{c}1.252 \\
(5.53)^{\star \star \star}\end{array}$ \\
\hline $\mathrm{SSA}_{\mathrm{t}}{ }^{*} \mathrm{r} 2002$ & & & $\begin{array}{c}8.821 \\
(4.50)^{* \star * *}\end{array}$ & & $\begin{array}{c}4.018 \\
(2.04)^{\star}\end{array}$ & \\
\hline $\mathrm{PV}_{\mathrm{t}}{ }^{*} \mathrm{r} 2002$ & & & & $\begin{array}{c}4.451 \\
(4.94)^{* \star * *}\end{array}$ & & $\begin{array}{c}3.265 \\
(3.61)^{\star \star \star}\end{array}$ \\
\hline $\mathrm{RR}_{\mathrm{t}}{ }^{*} \mathrm{r} 2002$ & & & $\begin{array}{c}0.232 \\
(3.04)^{\star \star}\end{array}$ & $\begin{array}{c}0.300 \\
(3.89)^{\star \star \star}\end{array}$ & $\begin{array}{c}\mathbf{0 . 1 5 1} \\
(1.97)^{\star}\end{array}$ & $\begin{array}{c}0.252 \\
(3.26)^{\star \star *}\end{array}$ \\
\hline r2002 & & & $\begin{array}{c}-0.763 \\
(-10.37)^{\star \star \star}\end{array}$ & $\begin{array}{c}-0.843 \\
(-11.04)^{\star \star \star}\end{array}$ & $\begin{array}{c}-0.689 \\
(-9.31)^{\star \star \star}\end{array}$ & $\begin{array}{c}-0.787 \\
(-10.24)^{\star \star \star}\end{array}$ \\
\hline low60 & & & & & $\begin{array}{c}0.205 \\
(4.45)^{\star \star \star}\end{array}$ & $\begin{array}{c}0.224 \\
(5.01)^{\star \star *}\end{array}$ \\
\hline low61 & & & & & $\begin{array}{l}-0.035 \\
(-0.46)\end{array}$ & $\begin{array}{l}-0.001 \\
(-0.01)\end{array}$ \\
\hline low62 & & & & & $\begin{array}{c}-0.587 \\
(-5.68)^{\star * *}\end{array}$ & $\begin{array}{c}-0.554 \\
(-5.38)^{* * \star}\end{array}$ \\
\hline low63 & & & & & $\begin{array}{c}-0.922 \\
(-6.42)^{\star \star \star \star}\end{array}$ & $\begin{array}{c}-0.878 \\
(-6.14)^{\star \star \star \star}\end{array}$ \\
\hline low64 & & & & & $\begin{array}{c}-1.885 \\
(-9.73)^{\star \star \star *}\end{array}$ & $\begin{array}{c}-1.899 \\
(-9.80)^{\star \star \star *}\end{array}$ \\
\hline top64 & & & & & $\begin{array}{c}-0.546 \\
(-2.26)^{\star}\end{array}$ & $\begin{array}{l}-0.383 \\
(-1.61)\end{array}$ \\
\hline top65 & & & & & $\begin{array}{c}-1.509 \\
(-11.52)^{\star * *}\end{array}$ & $\begin{array}{c}-1.415 \\
(-11.07)^{\star \star \star}\end{array}$ \\
\hline & & US, SECTC & Y AND OTH & HISTORY R & ABLES & \\
\hline$\overline{\mathrm{I}_{\mathrm{t}-1}}$ & $\begin{array}{c}-1.577 \\
(-39.51)^{* * *}\end{array}$ & $\begin{array}{c}-1.577 \\
(-39.52)^{\star \star \star}\end{array}$ & $\begin{array}{c}-1.551 \\
(-38.65)^{\star \star \star *}\end{array}$ & $\begin{array}{c}-1.556 \\
(-38.77)^{\star \star \star}\end{array}$ & $\begin{array}{c}-1.575 \\
(-39.05)^{\star \star * *}\end{array}$ & $\begin{array}{c}-1.577 \\
(-39.10)^{\star \star \star}\end{array}$ \\
\hline$u_{t-1}$ & $\begin{array}{c}0.942 \\
(25.21)^{* * *}\end{array}$ & $\begin{array}{c}0.934 \\
(24.98)^{\star \star * \star}\end{array}$ & $\begin{array}{c}0.965 \\
(25.72)^{\star \star \star}\end{array}$ & $\begin{array}{c}0.952 \\
(25.33)^{\star \star \star *}\end{array}$ & $\begin{array}{c}0.954 \\
(25.31)^{\star \star \star}\end{array}$ & $\begin{array}{c}0.947 \\
(25.09)^{\star \star \star *}\end{array}$ \\
\hline numrel & $\begin{array}{c}-0.022 \\
(-11.82)^{\star \star \star *}\end{array}$ & $\begin{array}{c}-0.022 \\
(-11.74)^{\star * \star}\end{array}$ & $\begin{array}{c}-0.021 \\
(-11.11)^{\star \star *}\end{array}$ & $\begin{array}{c}-0.021 \\
(-11.06)^{* * *}\end{array}$ & $\begin{array}{c}-0.023 \\
(-11.74)^{\star * *}\end{array}$ & $\begin{array}{c}-0.023 \\
(-11.66)^{\star * \star}\end{array}$ \\
\hline t x numrel & $\begin{array}{c}\mathbf{0 . 0 0 4} \\
(9.03)^{\star \star \star}\end{array}$ & $\begin{array}{c}\mathbf{0 . 0 0 4} \\
(8.97)^{\star \star \star}\end{array}$ & $\begin{array}{c}0.004 \\
(8.68)^{\star \star \star}\end{array}$ & $\begin{array}{c}0.004 \\
(8.65)^{\star \star \star}\end{array}$ & $\begin{array}{c}0.004 \\
(9.10)^{\star \star \star}\end{array}$ & $\begin{array}{c}0.004 \\
(9.04)^{* * *}\end{array}$ \\
\hline meanlenght & $\begin{array}{l}\mathbf{0 . 0 0 2} \\
(0.75)\end{array}$ & $\begin{array}{l}\mathbf{0 . 0 0 2} \\
(0.73)\end{array}$ & $\begin{array}{l}0.003 \\
(0.96)\end{array}$ & $\begin{array}{l}\mathbf{0 . 0 0 3} \\
(1.01)\end{array}$ & $\begin{array}{l}\mathbf{0 . 0 0 5} \\
(1.57)\end{array}$ & $\begin{array}{l}0.005 \\
(1.58)\end{array}$ \\
\hline t $x$ meanlenght & $\begin{array}{c}0.003 \\
(3.85)^{* * \star}\end{array}$ & $\begin{array}{c}0.003 \\
(3.92)^{\star \star \star \star}\end{array}$ & $\begin{array}{c}0.003 \\
(3.43)^{\star \star \star *}\end{array}$ & $\begin{array}{c}0.003 \\
(3.40)^{\star * \star}\end{array}$ & $\begin{array}{c}0.002 \\
(2.56)^{*}\end{array}$ & $\begin{array}{c}0.002 \\
(2.61)^{\star *}\end{array}$ \\
\hline serv & $\begin{array}{l}-0.003 \\
(-0.07)\end{array}$ & $\begin{array}{l}-0.001 \\
(-0.02)\end{array}$ & $\begin{array}{l}\mathbf{0 . 0 2 0} \\
(0.50)\end{array}$ & $\begin{array}{l}\mathbf{0 . 0 2 2} \\
(0.54)\end{array}$ & $\begin{array}{l}0.023 \\
(0.58)\end{array}$ & $\begin{array}{l}0.024 \\
(0.60)\end{array}$ \\
\hline t $x$ serv & $\begin{array}{l}-0.020 \\
(-1.67)\end{array}$ & $\begin{array}{c}-0.022 \\
(-1.81)^{*}\end{array}$ & $\begin{array}{c}-0.024 \\
(-2.01)^{\star}\end{array}$ & $\begin{array}{c}-0.026 \\
(-2.13)^{\star}\end{array}$ & $\begin{array}{c}-0.027 \\
(-2.22)^{\star}\end{array}$ & $\begin{array}{c}-0.028 \\
(-2.30)^{*}\end{array}$ \\
\hline
\end{tabular}


(cont...)

\begin{tabular}{|c|c|c|c|c|c|c|}
\hline \multicolumn{7}{|c|}{ PERSONAL CHARACTERISTICS \& OTHERS } \\
\hline univ & -0.729 & -0.751 & -0.706 & -0.716 & -0.779 & -0.794 \\
\hline & $(-10.46)^{\star \star \star}$ & $(-10.82)^{\star \star \star \star}$ & $(-10.10)^{\star \star \star}$ & $(-10.28)^{\star \star \star}$ & $(-10.95)^{\star \star \star \star}$ & $(-11.18)^{\star \star \star}$ \\
\hline \multirow[t]{2}{*}{ t x univ } & -0.078 & -0.068 & -0.086 & -0.079 & -0.038 & -0.029 \\
\hline & $(-4.02)^{\star \star *}$ & $(-3.57)^{\star \star \star}$ & $(-4.39)^{\star \star \star}$ & $(-4.15)^{\star \star \star \star}$ & $(-1.89)$ & $(-1.49)$ \\
\hline \multirow[t]{2}{*}{ disab } & -1.578 & -1.586 & -1.468 & -1.485 & -1.484 & -1.498 \\
\hline & $(-8.28)^{\star \star \star *}$ & $(-8.34)^{\star \star \star *}$ & $(-7.64)^{* * *}$ & $(-7.74)^{\star \star \star *}$ & $(-7.70)^{\star * * *}$ & $(-7.78)^{\star \star \star *}$ \\
\hline \multirow[t]{2}{*}{ otherben } & -2.981 & -2.970 & -2.978 & -2.972 & -3.016 & -3.015 \\
\hline & $(-17.55)^{* * *}$ & $(-17.54)^{\star \star \star \star}$ & $(-17.39)^{\star \star *}$ & $(-17.41)^{* \star *}$ & $(-17.54)^{\star \star \star}$ & $(-17.55)^{\star \star \star *}$ \\
\hline \multirow[t]{2}{*}{ age61 } & -0.015 & -0.037 & -0.069 & -0.095 & 0.098 & 0.069 \\
\hline & $(-0.06)$ & $(-0.15)$ & $(-0.29)$ & $(-0.40)$ & $(0.40)$ & $(0.28)$ \\
\hline \multirow[t]{2}{*}{ age62 } & -1.047 & -1.076 & -1.055 & -1.087 & -0.767 & -0.791 \\
\hline & $(-3.70)^{\star \star \star}$ & $(-3.80)^{\star \star \star}$ & $(-3.70)^{\star \star \star}$ & $(3.81)^{\star \star \star}$ & $(-2.48)^{*}$ & $(-2.56)^{*}$ \\
\hline \multirow[t]{2}{*}{ age63 } & -0.710 & -0.739 & -0.725 & -0.759 & -0.098 & -0.134 \\
\hline & $(-2.50)^{\star}$ & $(-2.59)^{\star \star}$ & $(-2.54)^{\star}$ & $(-2.65)^{\star \star}$ & $(-0.32)$ & $(-0.44)$ \\
\hline \multirow[t]{2}{*}{ age64 } & -0.712 & -0.759 & -0.686 & -0.739 & 0.247 & 0.213 \\
\hline & $(-2.46)^{\star}$ & $(-2.63)^{\star *}$ & $(-2.36)^{\star}$ & $(-2.55)^{\star}$ & $(0.78)$ & $(0.67)$ \\
\hline \multirow[t]{2}{*}{ age65 } & 2.813 & 2.788 & 2.865 & 2.834 & 3.271 & 3.272 \\
\hline & $(10.94)^{\star \star \star}$ & $(10.84)^{\star \star \star}$ & $(11.09)^{\star * \star}$ & $(10.96)^{\star \star \star \star}$ & $(12.34)^{\star * *}$ & $(12.33)^{\star \star \star *}$ \\
\hline \multirow[t]{2}{*}{ cycle } & 0.241 & 0.246 & 0.111 & 0.119 & 0.125 & 0.131 \\
\hline & $(16.89)^{\star \star \star}$ & $(17.18)^{\star \star \star}$ & $(5.94)^{\star \star \star}$ & $(6.42)^{\star \star \star \star}$ & $(6.69)^{\star \star \star}$ & $(7.03)^{\star \star \star}$ \\
\hline \multicolumn{7}{|c|}{ DURATION VARIABLES } \\
\hline \multirow[t]{2}{*}{ g1 } & -0.514 & -0.540 & -0.591 & -0.615 & -0.331 & -0.370 \\
\hline & $(-1.96$ & $(-2.06)^{\star}$ & $(-2.24)^{\star}$ & $(-2.33)^{*}$ & $(-1.23)$ & $(-1.37)$ \\
\hline \multirow[t]{2}{*}{ g2 } & -1.703 & -1.733 & -1.697 & -1.723 & -1.539 & -1.572 \\
\hline & $(-6.76)^{\star \star \star \star}$ & $(-6.88)^{\star \star \star *}$ & $\left(-6.74^{\star \star \star}\right.$ & $(-64.85)^{\star \star \star}$ & $(-6.02)^{* * *}$ & $(-6.15)^{\star \star \star *}$ \\
\hline \multirow[t]{2}{*}{ g3 } & -0.522 & -0.557 & -0.538 & -0.567 & -0.442 & -0.483 \\
\hline & $(-2.06)^{*}$ & $(-2.20)^{\star}$ & $(-2.11)^{*}$ & $(-2.22)^{*}$ & $(-1.64)$ & $(-1.79)$ \\
\hline \multirow[t]{2}{*}{ g4 } & -0.858 & -0.904 & -0.856 & -0.891 & -1.094 & -1.128 \\
\hline & $(-3.52)^{\star \star \star *}$ & $(-3.72)^{\star \star \star}$ & $(-3.50)^{\star \star \star}$ & $(-3.65)^{\star \star \star \star}$ & $(-4.32)^{\star \star * \star}$ & $(-4.45)^{\star \star \star}$ \\
\hline \multirow[t]{2}{*}{ g5 } & 0.054 & 0.027 & 0.028 & 0.016 & -0.494 & -0.519 \\
\hline & $(0.22)$ & $(0.11)$ & $(0.12)$ & $(0.07)$ & $(-1.95)$ & $(-2.05)^{*}$ \\
\hline \multirow[t]{2}{*}{ cons } & -2.328 & -2.264 & -1.422 & -1.306 & -1.731 & -1.635 \\
\hline & $(-3.82)^{\star * * *}$ & $(-3.71)^{\star \star \star}$ & $(-2.30)^{*}$ & $(-2.12)^{*}$ & $(-2.76)^{* \star}$ & $(-24602)^{\star \star}$ \\
\hline
\end{tabular}

$\left({ }^{*}\right)$ Notes:

Dependent variable is 1 if person retires and 0 otherwise, conditioned on not having retired before. Monetary values are in 1,000,000 euros, prices 2006. Z-values are in parenthesis. Statistical significance: * $p<0.05 ;{ }^{* *} p<0.01 ; * * * 0<0.001$. Coefficients of Autonomous Communities not resported. Prob $>$ chi $2=0$.

Model A represents the basic model. Model B includes Model A and changes in 2002 regulation as control variables. Model C includes Model B and income levels as control variables. 


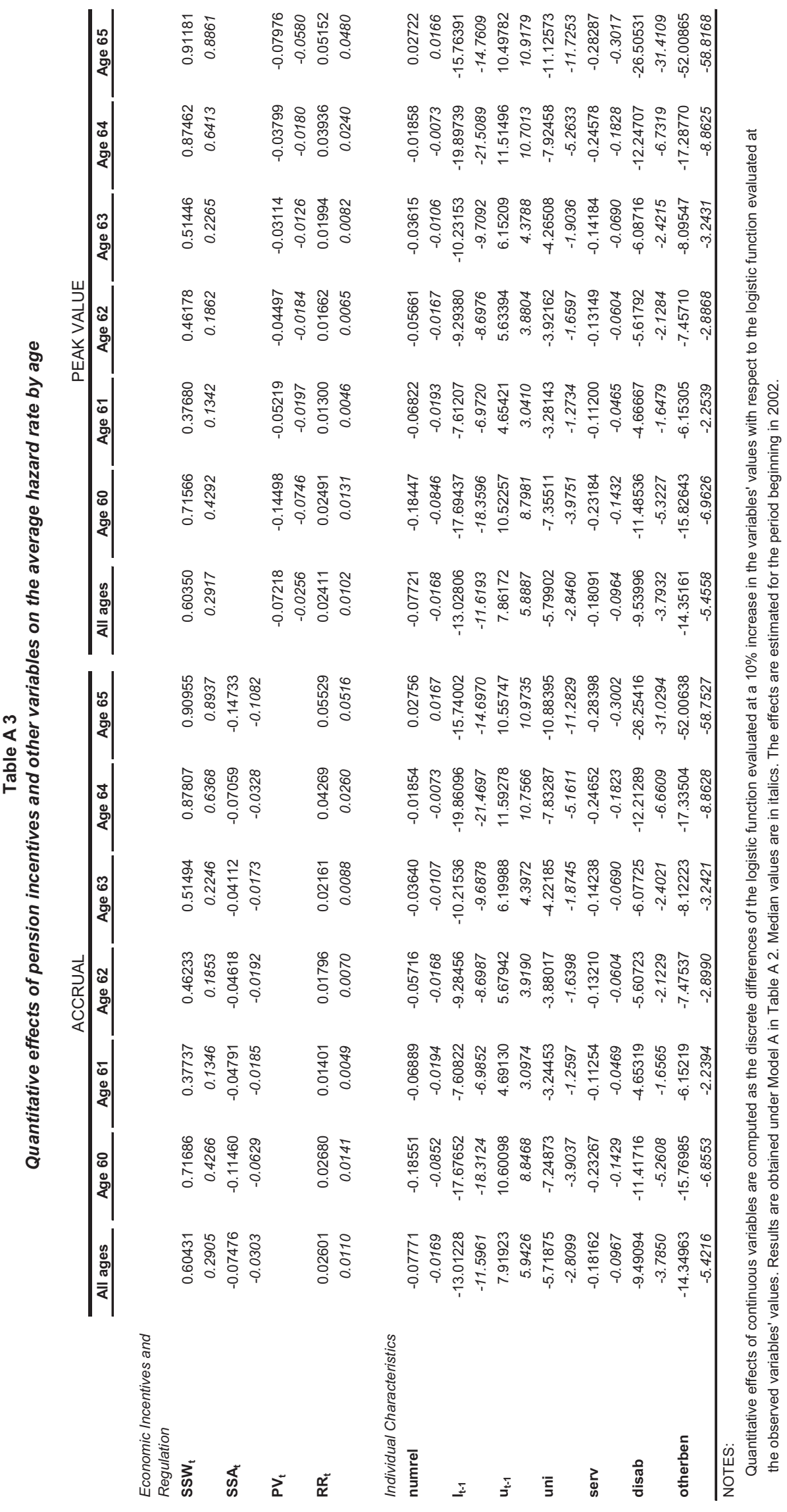


Table A 4

Quantitative effects of pension incentives and other variables on the average hazard rate for ages between 60 and 65

\begin{tabular}{|c|c|c|c|c|c|c|c|c|}
\hline & \multicolumn{4}{|c|}{ MODEL B } & \multicolumn{4}{|c|}{ MODEL C } \\
\hline & \multicolumn{2}{|c|}{ ACCRUAL } & \multicolumn{2}{|c|}{ PEAK VALUE } & \multicolumn{2}{|c|}{ ACCRUAL } & \multicolumn{2}{|c|}{ PEAK VALUE } \\
\hline & mean & median & mean & median & mean & median & mean & median \\
\hline \multicolumn{9}{|l|}{$\begin{array}{l}\text { Economic Incentives and } \\
\text { Regulation }\end{array}$} \\
\hline ssw $_{t}$ & 0.71796 & 0.3355 & 0.71724 & 0.3356 & 0.72477 & 0.3316 & 0.71524 & 0.3285 \\
\hline $\mathrm{SSA}_{\mathrm{t}}$ & -0.03813 & -0.0150 & & & -0.05987 & -0.0232 & & \\
\hline $\mathrm{PV}_{\mathrm{t}}$ & & & -0.03802 & -0.0129 & & & -0.03497 & -0.0121 \\
\hline $\mathbf{R R}_{\mathrm{t}}$ & 0.08219 & 0.0336 & 0.08559 & 0.0351 & 0.03570 & 0.0147 & 0.06126 & 0.0252 \\
\hline r2002 overall change & -2.25680 & -0.9702 & -2.22498 & -0.9991 & -1.92871 & -0.8550 & -1.95254 & -0.8653 \\
\hline \multicolumn{9}{|l|}{ r2002 change } \\
\hline low60 & & & & & 1.62710 & 0.8772 & 1.78145 & 0.9653 \\
\hline low61 & & & & & -0.26814 & -0.1388 & -0.00481 & -0.0025 \\
\hline low62 & & & & & -4.06336 & -1.8863 & -3.86059 & -1.8065 \\
\hline low64 & & & & & -10.06721 & -3.8245 & -10.12212 & -3.8505 \\
\hline top64 & & & & & -3.79020 & -1.7773 & -2.74440 & -1.3249 \\
\hline top65 & & & & & -8.60682 & -3.4529 & -8.23754 & -3.3657 \\
\hline \multicolumn{9}{|l|}{ Individual Characteristics } \\
\hline numrel & -0.06679 & -0.0140 & -0.06649 & -0.0139 & -0.07140 & -0.0150 & -0.07098 & -0.0149 \\
\hline$I_{t-1}$ & -12.35680 & -10.8762 & -12.39243 & -10.8844 & -12.52456 & -10.9361 & -12.55584 & -10.9680 \\
\hline $\mathbf{u}_{\mathrm{t}-1}$ & 7.88561 & 5.8823 & 7.76664 & 5.7665 & 7.75133 & 5.6599 & 7.69776 & 5.6092 \\
\hline uni & -5.48050 & -2.6384 & -5.49809 & -2.6548 & -5.59620 & -2.6804 & -5.63769 & -2.7072 \\
\hline serv & -0.03528 & -0.0184 & -0.03166 & -0.0165 & -0.03040 & -0.0160 & -0.03175 & -0.0167 \\
\hline disab & -8.74993 & -3.4459 & -8.82212 & -3.4737 & -8.76336 & -3.4515 & -8.82900 & -3.4802 \\
\hline otherben & -13.93090 & -5.0912 & -13.91856 & -5.1202 & -13.91094 & -5.0656 & -13.91999 & -5.0940 \\
\hline
\end{tabular}

NOTES:

Quantitative effects of the continuous variables are computed as the discrete differences of the logistic function evaluated at a $10 \%$ increase in the variables' values with respect to the logistic function evaluated at the observed variables' values.

Results are obtained under Models B and C in Table A2. The effects are estimated for the period beginning in 2002. 
BANCO DE ESPAÑA PUBLICATIONS

\section{WORKING PAPERS}

0801 ENRIQUE BENITO: Size, growth and bank dynamics.

0802 RICARDO GIMENO AND JOSÉ MANUEL MARQUÉS: Uncertainty and the price of risk in a nominal convergence process.

0803 ISABEL ARGIMÓN AND PABLO HERNÁNDEZ DE COS: Los determinantes de los saldos presupuestarios de las Comunidades Autónomas.

0804 OLYMPIA BOVER: Wealth inequality and household structure: US vs. Spain.

0805 JAVIER ANDRÉS, J. DAVID LÓPEZ-SALIDO AND EDWARD NELSON: Money and the natural rate of interest: structural estimates for the United States and the euro area.

0806 CARLOS THOMAS: Search frictions, real rigidities and inflation dynamics.

0807 MAXIMO CAMACHO AND GABRIEL PEREZ-QUIROS: Introducing the EURO-STING: Short Term INdicator of Euro Area Growth.

0808 RUBÉN SEGURA-CAYUELA AND JOSEP M. VILARRUBIA: The effect of foreign service on trade volumes and trade partners.

0809 AITOR ERCE: A structural model of sovereign debt issuance: assessing the role of financial factors.

0810 ALICIA GARCÍA-HERRERO AND JUAN M. RUIZ: Do trade and financial linkages foster business cycle synchronization in a small economy?

0811 RUBÉN SEGURA-CAYUELA AND JOSEP M. VILARRUBIA: Uncertainty and entry into export markets.

0812 CARMEN BROTO AND ESTHER RUIZ: Testing for conditional heteroscedasticity in the components of inflation.

0813 JUAN J. DOLADO, MARCEL JANSEN AND JUAN F. JIMENO: On the job search in a model with heterogeneous jobs and workers.

0814 SAMUEL BENTOLILA, JUAN J. DOLADO AND JUAN F. JIMENO: Does immigration affect the Phillips curve? Some evidence for Spain.

0815 ÓSCAR J. ARCE AND J. DAVID LÓPEZ-SALIDO: Housing bubbles.

0816 GABRIEL JIMÉNEZ, VICENTE SALAS-FUMÁS AND JESÚS SAURINA: Organizational distance and use of collateral for business loans.

0817 CARMEN BROTO, JAVIER DÍAZ-CASSOU AND AITOR ERCE-DOMÍNGUEZ: Measuring and explaining the volatility of capital flows towards emerging countries.

0818 CARLOS THOMAS AND FRANCESCO ZANETTI: Labor market reform and price stability: an application to the Euro Area.

0819 DAVID G. MAYES, MARÍA J. NIETO AND LARRY D. WALL: Multiple safety net regulators and agency problems in the EU: Is Prompt Corrective Action partly the solution?

0820 CARMEN MARTÍNEZ-CARRASCAL AND ANNALISA FERRANDO: The impact of financial position on investment: an analysis for non-financial corporations in the euro area.

0821 GABRIEL JIMÉNEZ, JOSÉ A. LÓPEZ AND JESÚS SAURINA: Empirical analysis of corporate credit lines.

0822 RAMÓN MARÍA-DOLORES: Exchange rate pass-through in new Member States and candidate countries of the EU.

0823 IGNACIO HERNANDO, MARÍA J. NIETO AND LARRY D. WALL: Determinants of domestic and cross-border bank acquisitions in the European Union.

0824 JAMES COSTAIN AND ANTÓN NÁKOV: Price adjustments in a general model of state-dependent pricing.

0825 ALFREDO MARTÍN-OLIVER, VICENTE SALAS-FUMÁS AND JESÚS SAURINA: Search cost and price dispersion in vertically related markets: the case of bank loans and deposits.

0826 CARMEN BROTO: Inflation targeting in Latin America: Empirical analysis using GARCH models.

0827 RAMÓN MARÍA-DOLORES AND JESÚS VAZQUEZ: Term structure and the estimated monetary policy rule in the eurozone.

0828 MICHIEL VAN LEUVENSTEIJN, CHRISTOFFER KOK SØRENSEN, JACOB A. BIKKER AND ADRIAN VAN RIXTEL: Impact of bank competition on the interest rate pass-through in the euro area.

0829 CRISTINA BARCELÓ: The impact of alternative imputation methods on the measurement of income and wealth: Evidence from the Spanish survey of household finances.

0830 JAVIER ANDRÉS AND ÓSCAR ARCE: Banking competition, housing prices and macroeconomic stability.

0831 JAMES COSTAIN AND ANTÓN NÁKOV: Dynamics of the price distribution in a general model of state-dependent pricing.

1. Previously published Working Papers are listed in the Banco de España publications catalogue. 
0832 JUAN A. ROJAS: Social Security reform with imperfect substitution between less and more experienced workers.

0833 GABRIEL JIMÉNEZ, STEVEN ONGENA, JOSÉ LUIS PEYDRÓ AND JESÚS SAURINA: Hazardous times for monetary policy: What do twenty-three million bank loans say about the effects of monetary policy on credit risk-taking?

0834 ENRIQUE ALBEROLA AND JOSÉ MARÍA SERENA: Sovereign external assets and the resilience of global imbalances.

0835 AITOR LACUESTA, SERGIO PUENTE AND PILAR CUADRADO: Omitted variables in the measure of a labour quality index: the case of Spain.

0836 CHIARA COLUZZI, ANNALISA FERRANDO AND CARMEN MARTÍNEZ-CARRASCAL: Financing obstacles and growth: An analysis for euro area non-financial corporations.

0837 ÓSCAR ARCE, JOSÉ MANUEL CAMPA AND ÁNGEL GAVILÁN: asymmetric collateral requirements and output composition.

0838 ÁNGEL GAVILÁN AND JUAN A. ROJAS: Solving Portfolio Problems with the Smolyak-Parameterized Expectations Algorithm.

0901 PRAVEEN KUJAL AND JUAN RUIZ: International trade policy towards monopoly and oligopoly.

0902 CATIA BATISTA, AITOR LACUESTA AND PEDRO VICENTE: Micro evidence of the brain gain hypothesis: The case of Cape Verde.

0903 MARGARITA RUBIO: Fixed and variable-rate mortgages, business cycles and monetary policy.

0904 MARIO IZQUIERDO, AITOR LACUESTA AND RAQUEL VEGAS: Assimilation of immigrants in Spain: A longitudinal analysis.

0905 ÁNGEL ESTRADA: The mark-ups in the Spanish economy: international comparison and recent evolution.

0906 RICARDO GIMENO AND JOSÉ MANUEL MARQUÉS: Extraction of financial market expectations about inflation and interest rates from a liquid market.

0907 LAURA HOSPIDO: Job changes and individual-job specific wage dynamics.

0908 M. ${ }^{a}$ DE LOS LLANOS MATEA AND JUAN S. MORA: La evolución de la regulación del comercio minorista en España y sus implicaciones macroeconómicas.

0909 JAVIER MENCÍA AND ENRIQUE SENTANA: Multivariate location-scale mixtures of normals and mean-varianceskewness portfolio allocation.

0910 ALICIA GARCÍA-HERRERO, SERGIO GAVILÁ AND DANIEL SANTABÁRBARA: What explains the low profitability of Chinese banks?

0911 JAVIER MENCÍA: Assessing the risk-return trade-off in loans portfolios.

0912 MAXIMO CAMACHO AND GABRIEL PEREZ-QUIROS: Ñ-STING: España Short Term INdicator of Growth.

0913 RAQUEL VEGAS, ISABEL ARGIMÓN, MARTA BOTELLA AND CLARA I. GONZÁLEZ: Retirement behaviour and retirement incentives in Spain.

\begin{tabular}{|r|c|}
\hline & Unidad de Publicaciones \\
BANCODE ESPAÑ & Alcalá, 522; 28027 Madrid \\
Eurosistema & Telephone +34 91 338 6363. Fax +34913386488 \\
& E-mail: publicaciones@bde.es \\
www.bde.es
\end{tabular}

